\title{
Sustainability and Quality Aspects of Different Table Egg Production Systems: A Literature Review
}

\author{
Szilvia Molnár *[i] and László Szőllósi \\ Institute of Applied Economics Sciences, Faculty of Economics and Business, University of Debrecen, \\ 4032 Debrecen, Hungary; szollosi.laszlo@econ.unideb.hu \\ * Correspondence: molnar.szilvia@econ.unideb.hu
}

Received: 19 August 2020; Accepted: 21 September 2020; Published: 23 September 2020

\begin{abstract}
Eggs are of considerable importance in feeding the population, as they are a relatively inexpensive and complex food source of very high biological value. The daily animal protein requirement for the human body can be covered with eggs in the cheapest way and with the lowest environmental impact. As animal welfare, as well as environmental and health awareness issues, become increasingly prominent in developed countries, consumer demand for eggs has also changed significantly in recent years, with an increasing number of consumers buying eggs produced in non-cage housing systems. In recent years, cage housing has been more frequently debated in EU member states. An initiative was launched in 2018 to end cage housing technologies and the sale of eggs produced in this way. However, in addition to animal welfare, a number of other factors need to be considered in relation to sustainable production. For this reason, the aim of this research is to provide a comprehensive overview of the sustainability issues of various housing technologies, as well as quality factors affecting consumer health and egg consumption based on the relevant international references and databases. Although there is a growing demand for products produced in non-cage housing systems due to the increasing relevance of environmental protection, health awareness and animal welfare issues in Western societies, research has shown that non-caged production is not the best solution for environmentally, socially and economically sustainable egg production.
\end{abstract}

Keywords: animal health; consumer preferences; economic issues; efficiency; environmental aspects; food safety; health awareness; non-cage housing systems; welfare

\section{Introduction}

It is increasingly recognized that eggs are a "miracle food" with the same biological value as breast milk, containing nearly 40 proteins, including bactericidal, potent antigenic and antihypertensive proteins. In addition, eggs contain 18 different amino acids, nine of which are essential. Eggs are a highly nutritious food containing vital vitamins $\left(\mathrm{A}, \mathrm{D}, \mathrm{E}, \mathrm{B}_{1}, \mathrm{~B}_{2}, \mathrm{~B}_{3}\right.$, pantothenic acid, $\mathrm{B}_{6}$, folic acid, vitamin $\mathrm{B}_{12}$ ) and are very rich in minerals ( $\mathrm{Fe}, \mathrm{Zn}, \mathrm{Cu}, \mathrm{Mg}$, I, Se, $\left.\mathrm{Ca}, \mathrm{P}, \mathrm{K}\right)$. Eggs contain an optimal proportion of saturated and unsaturated fatty acids, while they do not contain carbohydrates and trans fats. In recent years, several studies [1-4] addressed the impact of egg consumption on the human body. The obtained results show that eggs also contain a number of nutrients that, in addition to being part of the essential diet, also play a significant role in maintaining health. Contrary to the previous misconception about cholesterol [4], recent research results show that eggs do not increase cholesterol levels or the risk of related diseases [5]. For this reason, international recommendations suggest the regular consumption of eggs as part of a healthy diet [6,7]. It is important to note that the human body's daily need for animal protein can be covered with eggs in the cheapest way and with the least environmental impact. In addition to being an essential food, eggs play an important role in maintaining health due to their functional properties and can also be easily enriched with 
beneficial ingredients. The positive properties of eggs include the improvement of brain functions, fetal development and the immune system, while their consumption reduces the risk of cardiovascular and tumor diseases, as well as age-related eye diseases (cataract, macular degeneration), thrombosis, vasoconstriction and the age-related loss of skeletal muscle mass and function (sarcopenia) [5,8-15].

Global hen egg production increased by $24.4 \%$ over the past decade, bringing production to close to 76.8 million tons in 2018, which is expected to increase further in the future, as the demand for animal protein increases [16]. About $35 \%$ of the amount of eggs produced globally originates from China. In addition, a significant amount of eggs is produced in the U.S. (6.5 million tons) and India (5.2 million tons). The top three countries account for nearly 53\% of world egg production [16].

There was a slight increase in egg production in the EU28 countries in the last decade $(+5.8 \%)$, but the European Commission [17] forecasts that Member States' production could increase by a further $9 \%$ by 2030 . The amount of eggs produced by the EU28 countries accounted for $9.3 \%$ of global production in 2018, with the most significant producing countries being France $(11.9 \%)$, Germany (11.9\%), Spain (11.8\%), the United Kingdom and Northern Ireland (10.9\%), Italy (10.9\%), the Netherlands $(9.9 \%)$ and Poland $(9.2 \%)$, which accounted for almost three quarters of EU production. Self-sufficiency in the EU28 has ranged between 102 and 104\% in recent years as a result of export orientation. The EU28 countries' exports of eggs and egg products amounted to 219 thousand tons in 2018, making it the world's second largest exporter. In contrast, imports of eggs and egg products were much lower, amounting to 27 thousand tons in 2018 [17].

Council Directive 99/74/EC has a great impact on the EU egg sector, as it lays down the minimum requirements for the protection of laying hens. According to the directive and related regulations, laying hens in the EU Member States can only be kept in EU-compliant enriched cages or non-caged housing from 2012, and eggs placed on the market can only come from such systems.

There are several housing systems used in egg production. These may be caged or non-cage systems. Caged housing systems can be classified as conventional cages and EU-compliant enriched (or furnished) cages, while non-cage systems are either barn (single-level), aviary (multilevel), free-range or organic housing. Enriched cages may offer more height and space than conventional cages and are equipped with a number of devices to meet the natural needs of laying hens (e.g., nest boxes, perches and a litter area which permits scratching and dust bathing) [18]. In the literature, non-cage systems are identified in many cases as alternative housing; however, the latter term refers to barn and aviary systems. Barn or floor management systems may either be pure indoor systems or combined with outdoor facilities. These are always single-level systems in which the ground floor, or part of it, is covered with litter. Aviaries are always multilevel systems, with several levels of perforated floors in addition to the ground floor. This system may also be either a pure indoor system or equipped with outdoor access. Moreover, outdoor systems may either be conventional free-range systems or organic systems [18]. Windhorst [19] reviews the advantages and disadvantages of housing systems from animal welfare aspects. A more detailed description of each housing technology can be found in LayWel [20] and in the study of Zhao et al. [21].

According to European Commission [22] data, in 2019, 47.8\% of laying hens were kept in enriched cages, $29.3 \%$ in barn and aviary systems, $17.0 \%$ in free-range housing, while the proportion of organic housing was only $5.9 \%$. However, the proportion of these housing systems is different in each Member State. In Malta, Lithuania, Portugal, Slovakia, Poland and Latvia, the vast majority of laying hens $(>80 \%)$ are kept in enriched cages. In contrast, non-caged housing is dominant in the Netherlands, Denmark, Sweden, Germany, Austria and Luxembourg.

In recent years, a number of studies have examined the quality, content and production characteristics of different housing systems and explored differences between them. Most of this research compares production in a cage system to a non-caged system, and only a small number of literature sources compare the housing types in the latter group (aviary, barn, free-range, organic housing). In addition to changes in macroeconomic factors over the past decade, consumer demand has also changed significantly at the global level. Consumers, especially in the EU28 countries, tend to 
increasingly prefer eggs from non-cage systems as they believe that eggs produced in these housing systems are of better quality than eggs produced in caged systems [23].

In 2018, a civic initiative called "End the Cage Age" was launched in the EU to end cage housing. The collection of signatures in support of the initiative ended in September 2019 with around 1.5 million signatures and is expected to be submitted to the European Commission in September 2020, which should take a position on the issue. In this context, several retail chains in Europe have recently announced that they do not plan to sell eggs originating from caged housing systems in their shops from 2025, which could have a significant impact on the situation of the egg sector in Member States where producers use cages. Caged housing is becoming a subject of debate among supporters of animal welfare and protection, as well as researchers and producers [24]. The impact of different housing systems on the health and behavior of birds is still considered a significant issue today. However, in addition to animal welfare, there are many aspects to sustainability, including economic issues, environmental factors, human health and food safety, as well as various social values [25]. Gunnarsson et al. [26] systematically mapped these factors based on scientific publications on poultry over the past two decades. The Coalition for Sustainable Egg Supply (CSES) project [27-29] evaluated three egg production systems (conventional cage, enriched colony, and cage-free aviary) in the U.S. from the aspects of animal behavior and well-being, environmental impact, egg safety and quality, food affordability, and worker health. Most of the scientific papers published on the CSES project are also processed in our study.

It is important to note that these systems not only affect the behavior, productivity and health of birds, but also have a major impact on the environment, as well as on egg quality, and thus indirectly on consumers (even from a health point of view) and consumer decisions [30]. For this reason, it is important to examine the possible environmental and economic effects of egg production and impacts on the quality of eggs in different systems, and how these effects influence consumers.

The aim of this research is to explore and compare the sustainability issues of different housing technologies, as well as quality factors affecting consumer health and egg consumption. More specifically, the following five subaims were formulated: to identify the effects of different housing systems on: (1) the quality aspect; (2) the environmental issues; (3) the animal welfare, animal health and food safety aspects; (4) the production efficiency and economic aspects of egg production; (5) to these patterns compared with consumer preferences.

\section{Materials and Methods}

In this study, qualitative research was performed through a systematic literature review. A systematic review seeks to systematically search for, appraise and synthesize research evidence and findings. The synthesis is typically a narrative and the analyses may be chronological, conceptual and thematic [31,32]. This qualitative research method is of an exploratory nature, making it possible to get to know the studied area in detail, as well as to explore and compare previous research results and their circumstances. Our results obtained in this manner cannot be quantified or measured; however, the aim of these examinations is to explore and understand the regularities between the environmental, economic and social effects of different housing systems.

The major international literature and databases related to the topic were reviewed and evaluated. Based on Boar et al. [32], the methodology used in our paper is summarized in Table 1. Relevant and up-to-date literature sources were collected using mainly Google Scholar, Web of Science and Scopus, while some data related to the egg sector were extracted from Food and Agriculture Organization of the United Nations (FAO) and European Commission (EC) databases. Technical literature databases were searched with the keywords listed in the table. Similarly to the work of Gunnarsson et al. [26], the fit of search results to the topic was judged based on their title and abstract. As a next step, a content analysis was performed on the selected literature. We also reviewed the bibliography of the literature collected in this way, and we expanded the range of relevant literature using the snowball method. If the quantity and the quality of results in the online databases were insufficient in relation to certain areas 
of the study, the sources used were supplemented with related publications collected by the authors in previous years. As a result, certain resources are not available electronically, only in printed form.

Table 1. Summary of methodology used in the study.

\begin{tabular}{l} 
Research Objectives \\
\hline (1) To identify the effects of different housing systems on the quality aspect of egg production. \\
(2) To identify the effects of different housing systems on the environmental issues of egg production. \\
(3) To identify the effects of different housing systems on the animal welfare, animal health and food safety \\
aspects of egg production. \\
(4) To identify the effects of different housing systems on the production efficiency and economic aspects of \\
egg production. \\
(5) To compare these patterns with consumer preferences.
\end{tabular}

\section{Initial Inclusion Criteria}

Documents available in Google Scholar, in Web of Science, in Scopus and materials collected for years by authors of this study.

\section{Setting the Inclusion Criteria}

(1) keywords: egg housing; non-cage egg production; alternative egg production; egg housing environment; environmental effect table egg in the different production system; ammonia contamination in eggs production; egg production emission; bacteriological contamination of eggshell; physical contamination of eggshell; eggs dioxin different housing system; contamination on eggshell; eggs contamination alternative system; antibiotic in egg production; antibiotic-free egg production; effect of housing system on egg quality; cleanliness of eggshell; the interior quality of eggshell; effect of eggshell quality; content of table hen eggs; laying hen housing productivity; production cost of eggs in the different housing system; consumer preferences eggs; consumer preference eggshell colour; housing system consumer preference; health awareness egg consumption; egg sustainability;

(2) relevant documents from the bibliography of selected papers;

(3) timeframe: 2010-2020;

(4) geographical limitation: Europe, North America;

(5) housing systems: cage housing (conventional and/or enriched/furnished cage) vs. non-cage housing (aviary and/or barn and/or free-range and/or organic); non-cage housing vs. non-cage housing;

\section{Applying the Exclusion Criteria}

After the reading of title and abstracts, only documents that were focused on

(1) the sustainability issues and quality aspects of egg production in various housing systems and

(2) egg consumer preferences were selected.

\section{Content Analysis}

In-depth analysis and classification of papers by key topics.

Overview and compare findings of selected papers.

\section{Critical Discussion and Conclusion}

In searching for literature sources, the results were mainly focused on the years between 2010 and 2020. Older sources were processed only if the main findings were not out of date. A geographical limitation was also set, mainly to include studies conducted in Europe and North America, enabling a focus on studies on production systems in similar economic and technological contexts. Research results from different geographical areas were included in the study only in small numbers. In line with the aim of the study, the primary objective was to explore the differences between conventional and enriched/furnished cage systems and aviary, barn, free-range, organic, and various non-cage systems. For this reason, sources focusing on only one housing system or those comparing only the characteristics of different cage systems were excluded. After applying the exclusion criteria, 104 articles were included in the review.

This study addresses the effects of different housing technologies on egg quality and content values, as well as environmental, animal welfare, animal health and food safety issues. Although egg-related consumer preferences were not highlighted in a separate subchapter, scientifically substantiated facts 
were compared with them when examining each issue. The synthesized results were presented in a narrative way and in tabular form, edited into subchapters according to each topic.

\section{Results}

In developed countries, especially in Europe and the USA, the issue of animal welfare is gaining prominence [33-38], similarly to environmental consciousness [39,40] and health awareness [41-43]. In line with this tendency, consumer demand for eggs has also changed significantly in recent years. This work provides a comprehensive review of different housing technologies in relation to the factors affecting egg quality, as well as environmental, animal welfare, animal health, food safety and economic issues.

\subsection{Egg Quality Issues}

An increasing number of consumers are recognizing the health benefits of egg proteins, vitamins and minerals. One of the most important aspects for consumers when choosing food is that the product is safe and healthy to eat [44], i.e., it does not contain substances that could endanger their health (microorganisms, mycotoxins, pesticides, antibiotics, etc.). In addition, there is a growing interest in products produced in an alternative way (cage-free, antibiotic-free, alternative feeding) [45,46]. Żakowska-Biemans and Tekień [47] found that price and housing system had the most significant importance in shaping Polish consumers' preferences, while other attributes such as egg size and package size were far less important. Many consumers believe that eggs from free-range and organic farming are healthier and of better quality than those produced in caged housing systems [29,46,48-50]. Thus, in line with recent nutritional trends, consumers demand healthy and balanced food products. For this reason, consumers also pay increased attention to the quality parameters of eggs [51].

Based on the findings of Senbeta et al. [52], it can be concluded that the color of the eggshell and egg yolk, egg size, as well as nutrient composition, significantly influence consumer attitudes and their choice of eggs during their purchases. Although consumers are not able to judge the internal characteristics of the egg during purchase, their decisions could be aided by the information about the content of the egg, presented on the packaging (extra yellow, enriched in vitamins, etc.).

Several researchers [53-57] state that the quality of table eggs is influenced by production factors such as the age of the hen, genetics, or feeding, and point out that the comparison of the quality of eggs from farms with different housing technologies should be treated with caution. Regarding different housing systems, there is no particular technology which is suitable for the production of eggs with superior quality [58], and the higher price of eggs from alternative housing does not necessarily mean a quality difference similar to that of prices [59]. However, several studies focus on the quality characteristics of eggs from different housing systems, as summarized in Table 2. These studies tend to conclude that housing systems have a significant effect on egg weight, shape, eggshell color, thickness, firmness and the characteristics of the egg white and egg yolk. Englmaierová et al. [60] found that housing technologies significantly influenced egg weight, and while eggs produced in aviary and enriched cage systems had higher average weights, eggs originating from barn housing systems had lower weights. Galic et al. [61] reported the same result, i.e., the largest and heaviest eggs were produced in enriched cage systems. Perić et al. [54] compared eggs from traditional caged systems, omega-3-enriched eggs and eggs from free-range housing in terms of their external and internal properties which affect egg quality, using samples from one of the largest supermarkets. As a result, a significant difference was found in the fat content of egg yolks, which was lower for eggs produced in traditional technology. Furthermore, free-range eggs showed better shell quality compared to products from caged housing systems. In addition, in the examined sample, the yolk of free-range eggs had the lightest color, which is a finding completely opposite to consumer expectations [62]. According to other research [61,63], free-range eggs and their yolks were heavier in weight and the latter was more intensely colored, while the shell of eggs produced in caged housing systems was thicker. At the same time, other indicators of egg quality (e.g., protein and shell weight, protein and yolk $\mathrm{pH}$ ) were not 
affected by the given housing technology [63]. In addition, the study of Minelli et al. [64] revealed that eggs produced in organic systems were lighter in weight and even eggshell fracture toughness was lower in organic farming than in traditional cage systems.

Table 2. Egg quality traits in different housing systems and different studies.

\begin{tabular}{|c|c|c|c|c|c|c|c|c|c|c|c|c|}
\hline \multirow{2}{*}{ Studies } & \multirow{2}{*}{$\begin{array}{l}\text { Analyzed } \\
\text { Housing } \\
\text { System }\end{array}$} & \multicolumn{11}{|c|}{ Evaluated Egg Quality Traits } \\
\hline & & EW & SI & ESC & EST & ESS & $\mathrm{AH} / \mathrm{W}$ & HU & YW & YC & $\mathrm{C} / \mathrm{N}$ & SC \\
\hline Minelli et al. (2007) [64] & $\mathrm{CC}, \mathrm{O}$ & $\sqrt{ }$ & - & - & - & - & $-/ \sqrt{ }$ & $\sqrt{ }$ & $\sqrt{ }$ & $\sqrt{ }$ & $\sqrt{ }$ & - \\
\hline Matt et al. (2009) [65] & $\mathrm{CC}, \mathrm{O}$ & - & - & - & - & - & - & - & - & - & $\sqrt{ }$ & - \\
\hline Yenice et al. (2016) [55] & Cage, FR & $\sqrt{ }$ & $\sqrt{ }$ & - & $\sqrt{ }$ & $\sqrt{ }$ & $\sqrt{ } /-$ & $\sqrt{ }$ & - & $\sqrt{ }$ & $\sqrt{ }$ & - \\
\hline Anderson (2011) [49] & Cage, FR & & & - & & & - & - & - & & $\sqrt{ }$ & - \\
\hline Küçükyılmaz et al. (2012) [66] & $\mathrm{CC}, \mathrm{O}$ & $\sqrt{ }$ & $\sqrt{ }$ & - & $\sqrt{ }$ & $\sqrt{ }$ & $\sqrt{ } /-$ & $\sqrt{ }$ & - & $\sqrt{ }$ & $\sqrt{ }$ & - \\
\hline Kralik et al. (2013) [63] & Cage, FR & $\sqrt{ }$ & $\sqrt{ }$ & - & $\sqrt{ }$ & $\sqrt{ }$ & $\sqrt{ } \sqrt{ }$ & $\sqrt{ }$ & $\sqrt{ }$ & $\sqrt{ }$ & & - \\
\hline Jones et al. (2014) [67] & $\mathrm{CC}, \mathrm{EC}, \mathrm{AV} / \mathrm{B}$ & $\sqrt{ }$ & - & - & - & $\sqrt{ }$ & $\sqrt{ } /-$ & $\sqrt{ }$ & - & - & - & - \\
\hline Samiullah and Chousalkar (2014) [68] & CC, FR & $\sqrt{ }$ & - & - & $\sqrt{ }$ & $\sqrt{ }$ & $\sqrt{ } /-$ & $\sqrt{ }$ & - & $\sqrt{ }$ & - & - \\
\hline Yang et al. (2014) [69] & Cage, FR & $\sqrt{ }$ & $\sqrt{ }$ & - & $\sqrt{ }$ & $\sqrt{ }$ & $\sqrt{ } /-$ & - & - & $\sqrt{ }$ & - & - \\
\hline Ferrante et al. (2015) [70] & $\mathrm{AV} / \mathrm{B}, \mathrm{O}$ & $\sqrt{ }$ & & - & & - & $-1 \sqrt{ }$ & - & $\sqrt{ }$ & - & - & $\sqrt{ }$ \\
\hline Englmaierová et al. (2017) [60] & $\mathrm{CC}, \mathrm{EC}, \mathrm{AV} / \mathrm{B}$ & $\sqrt{ }$ & $\sqrt{ }$ & - & $\sqrt{ }$ & $\sqrt{ }$ & $\sqrt{ }$ & $\sqrt{ }$ & 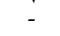 & - & - & - \\
\hline Yilmaz Dikmen et al. (2017) [71] & $\mathrm{CC}, \mathrm{EC}, \mathrm{FR}$ & $\sqrt{ }$ & $\sqrt{ }$ & $\sqrt{ }$ & $\sqrt{ }$ & - & $-1 \sqrt{ }$ & $\sqrt{ }$ & $\sqrt{ }$ & $\sqrt{ }$ & - & - \\
\hline Perić et al. (2016) [54] & $\mathrm{CC}, \mathrm{FR}$ & $\sqrt{ }$ & $\sqrt{ }$ & $\sqrt{ }$ & $\sqrt{ }$ & $\sqrt{ }$ & $\sqrt{ } /-$ & $\sqrt{ }$ & - & $\sqrt{ }$ & $\sqrt{ }$ & $\sqrt{ }$ \\
\hline Sokolowicz et al. (2018) [72] & $\mathrm{B}, \mathrm{FR}, \mathrm{O}$ & $\sqrt{ }$ & $\sqrt{ }$ & $\sqrt{ }$ & $\sqrt{ }$ & $\sqrt{ }$ & $\sqrt{ } /-$ & $\sqrt{ }$ & $\sqrt{ }$ & $\sqrt{ }$ & - & - \\
\hline Sokolowicz et al. (2018) [73] & $\mathrm{AV} / \mathrm{B}, \mathrm{FR}, \mathrm{O}$ & $\sqrt{ }$ & $\sqrt{ }$ & $\sqrt{ }$ & $\sqrt{ }$ & $\sqrt{ }$ & $\sqrt{ } /-$ & $\sqrt{ }$ & $\sqrt{ }$ & $\sqrt{ }$ & $\sqrt{ }$ & - \\
\hline Vlčková et al. (2018) [57] & EC, FR & $\sqrt{ }$ & - & - & $\sqrt{ }$ & $\sqrt{ }$ & -1 & - & - & - & - & - \\
\hline Zita et al. (2018) [56] & Cage, B & $\sqrt{ }$ & $\sqrt{ }$ & $\sqrt{ }$ & $\sqrt{ }$ & $\sqrt{ }$ & $-1-$ & $\sqrt{ }$ & - & $\sqrt{ }$ & - & - \\
\hline Galic et al. (2019) [61] & $\mathrm{EC}, \mathrm{AV} / \mathrm{B}, \mathrm{FR}$ & $\sqrt{ }$ & $\sqrt{ }$ & - & $\sqrt{ }$ & - & $-/ \sqrt{ }$ & - & $\sqrt{ }$ & - & - & - \\
\hline Kraus et al. (2019) [58] & $\mathrm{EC}, \mathrm{B}$ & $\sqrt{ }$ & $\sqrt{ }$ & $\sqrt{ }$ & $\sqrt{ }$ & $\sqrt{ }$ & $-/ \sqrt{ }$ & $\sqrt{ }$ & $\sqrt{ }$ & - & - & - \\
\hline Vlčková et al. (2019) [74] & $\mathrm{EC}, \mathrm{FR}$ & $\sqrt{ }$ & . & - & - & - & - & $\sqrt{ }$ & - & - & - & - \\
\hline Ghanima et al. (2020) [75] & Cage, B & $\sqrt{ }$ & - & - & $\sqrt{ }$ & - & - & $\sqrt{ }$ & - & - & $\sqrt{ }$ & - \\
\hline Popova et al. (2020) [76] & $\begin{array}{c}\text { Alternative } \\
\text { with pasture, B }\end{array}$ & $\sqrt{ }$ & $\sqrt{ }$ & - & $\sqrt{ }$ & - & $\sqrt{ } / \sqrt{ }$ & $\sqrt{ }$ & $\sqrt{ }$ & - & $\sqrt{ }$ & - \\
\hline
\end{tabular}

Conventional cage $(\mathrm{CC})$, enriched cage (EC), aviary (AV), barn (B), free-range (FR), organic (O), egg weight (EW), shape index (SI), eggshell color (ESC), eggshell thickness (EST), eggshell strength (ESS), albumen height/weight $(\mathrm{AH} / \mathrm{W})$, yolk weight $(\mathrm{YW})$, yolk color (YC), content/nutrient $(\mathrm{C} / \mathrm{N})$, shell cleanness (SC).

Other researchers have not confirmed the above-described findings [66,77]. De Reu et al. [77] analyzed the bacterial contamination of the air, as well as the quality of eggs and eggshells, and found only a small difference between enriched cage and non-cage systems, while the difference between barn and aviary housing systems was negligible. Although there is no correlation between eggshell color and egg content quality [78], the brown coloration of the shell is an important shell quality trait and has a positive influence on consumer preference in certain parts of the word [79]. Brown eggs dominate the markets of most of Europe, Southeast Asia, Australia, New Zealand, much of Africa and some countries in South America. In other regions of the world, consumers prefer white eggs $[30,80]$.

Several studies describe the differences in the composition of eggs from caged and non-cage housing systems. Based on the findings of Matt et al. [65], there is a significant difference between the eggs of hens kept in conventional and organic systems, as differences were found in their vitamin, cholesterol, calcium and potassium contents. The calcium content of organic eggs was significantly lower than that of those from conventional caged housing systems. The cholesterol and potassium concentrations were higher in the case of organic keeping. This finding is also confirmed by Küçükyılmaz et al. [66], who found lower omega-3 content in the yolks of eggs produced in organic systems than in eggs produced in the traditional system. Experts also point out that there may be significant differences in the feeding used in different types of housing systems, which can greatly affect the quality properties of eggs. The observed differences in experiments $[54,55,63-66,68,70,72,73,76,81]$ with different diets could also be traced back to feeding parameters. The research results of $[75,82]$ also support these findings, as they claim that differences/changes in feeding affect egg quality parameters even more directly than housing. Radu-Rasu et al. [83] stated that, under similar dietary conditions, non-cage systems resulted in hens producing eggs with higher nutritive values (lower concentrations of total lipids, cholesterol and gross energy) than in other systems. Similar results were obtained by two other studies $[69,71]$, i.e., the overall quality of eggs produced in a free-range system was better than that of eggs from conventional cage and enriched cage systems. In contrary, Kraus et al. [58] found 
that most of the values of the main quality traits were better in eggs from enriched cages compared to barns under similar feeding circumstances.

Sokolowicz et al. [72] examined the quality characteristics of eggs produced in different alternative housing systems and found differences in egg weight, shape and egg yolk color intensity between each system. The yolks of free-range and organic eggs are more intense in color than those produced in the barn system. For this reason, it can be concluded that (free-range) housing technologies which also utilize green areas are advantageous in this respect.

\subsection{Environmental Issues}

An increasing number of consumers are buying eggs produced in non-cage systems $[45,46]$ because, on the one hand, they believe that eggs produced in an alternative way are healthier and of better quality and, on the other hand, in the knowledge that they have done something to protect their health, as well as animals and the planet [84]. This point of view is confirmed by the research of Bombik et al. [85], according to which organic farming systems integrate environmentally friendly production practices, support biodiversity and the protection of natural resources, while ensuring animal welfare. Rahmani et al. [86] found that consumers perceived caged eggs as the type of eggs with the highest greenhouse gas emissions and water use, which is not true. Several environmental factors were measured and evaluated in different studies to compare different housing systems (Table 3). Research findings related to the environmental issues of egg production among different housing systems are summarized in Table 4.

Table 3. Environmental factors in different housing systems and different studies.

\begin{tabular}{|c|c|c|c|c|c|c|}
\hline \multirow[b]{2}{*}{ Studies } & \multirow{2}{*}{$\begin{array}{l}\text { Analyzed Housing } \\
\text { System }\end{array}$} & \multicolumn{5}{|c|}{ Evaluated Environmental Factors } \\
\hline & & $\begin{array}{c}\text { GHGE } \\
\mathrm{CO}_{2} / \mathrm{CH}_{4} / \mathrm{N}_{2} \mathrm{O}\end{array}$ & $\begin{array}{c}\mathrm{AE} \\
\mathrm{NH}_{3} / \mathrm{SO}_{2}\end{array}$ & $\mathrm{PO}_{4} / \mathrm{NO}_{3}$ & PM & $\begin{array}{c}\text { NRU } \\
\text { E/L/W/N }\end{array}$ \\
\hline Whyte (2002) [87] & Cage, B & $-/-/-$ & $\sqrt{ } /-$ & $-/-$ & $\sqrt{ }$ & $-/-|-|-$ \\
\hline Bessei et al. (2011) [88] & $\mathrm{CC}, \mathrm{EC}, \mathrm{AV}, \mathrm{B}, \mathrm{FR}$ & $\sqrt{ } / \sqrt{ } / \sqrt{ }$ & $\sqrt{ } /-$ & $-/-$ & - & $-/ \sqrt{ } /-/ \sqrt{ }$ \\
\hline Xin et al. (2011) [89] & cage, non-cage & $\sqrt{ } / \sqrt{ } / \sqrt{ }$ & $\sqrt{ } /-$ & $-/-$ & $\sqrt{ }$ & $\sqrt{ } / \sqrt{ } /-/-$ \\
\hline Dekker et al. (2011) [90] & $\mathrm{CC}, \mathrm{B}, \mathrm{FR}, \mathrm{O}$ & $\sqrt{ } / \sqrt{ } / \sqrt{ }$ & $\sqrt{ } / \sqrt{ }$ & $-/-$ & - & $\sqrt{ } / \sqrt{ } / \sqrt{ } / \sqrt{ }$ \\
\hline Shepherd et al. (2015) [91] & $\mathrm{CC}, \mathrm{EC}, \mathrm{AV}$ & $\sqrt{ } / \sqrt{ } /-$ & $\sqrt{ } /-$ & $-1-$ & $\sqrt{ }$ & $-/--/ \sqrt{ }$ \\
\hline Zhao et al. (2015) [92] & $\mathrm{CC}, \mathrm{EC}, \mathrm{AV}$ & $\sqrt{ } / \sqrt{ } / \sqrt{ }$ & $\sqrt{ } /-$ & $-/-$ & $\sqrt{ }$ & $-|-|-/-$ \\
\hline van Asselt et al. (2015) [93] & $\mathrm{EC}, \mathrm{B}, \mathrm{FR}, \mathrm{O}$ & $\sqrt{ } /-/-$ & $\sqrt{ } / \sqrt{ }$ & $\sqrt{ } / \sqrt{ }$ & $\sqrt{ }$ & $\sqrt{ } / \sqrt{ } / \sqrt{ } / \sqrt{ }$ \\
\hline Pelletier (2017) [94] & $\mathrm{CC}, \mathrm{EC}, \mathrm{B}, \mathrm{FR}, \mathrm{O}$ & $\sqrt{ } /-/-$ & $-/ \sqrt{ }$ & $\sqrt{/}-$ & - & $\sqrt{ } / \sqrt{ } /-/ \sqrt{ }$ \\
\hline
\end{tabular}

Conventional cage (CC), enriched cage (EC), aviary (AV), barn (B), free-range (FR), organic (O), greenhouse gas emission (GHGE), acidifying emissions (AE), particulate matter (PM), natural resources use (NRU), energy (E), land $(\mathrm{L})$, water $(\mathrm{W})$, nutrient $(\mathrm{N})$.

Egg production, similarly to other intensive productions, has a negative impact on the environment through greenhouse gas emissions, as well as soil and water pollution. Birds, feed, manure, and other equipment related to housing systems are potential sources of the environmental footprint regarding livestock management [95]. The livestock and manure management practices of different housing systems may result in varying sizes of environmental footprint [89]. Although table eggs are consumed worldwide as a valuable and inexpensive source of protein, there is still only a small number of studies addressing the environmental impacts of egg production [95].

In terms of environmental impact, caged systems are more favorable, as Horn [96] states that high-performance populations in highly concentrated housing systems provide the most efficient and least environmentally harmful solutions. Fróna et al. [97] highlight that intensive farming means the most effective utilization of agricultural land and water resources. Based on the findings summarized in Table 4, it can be concluded that resource use (water, forage area, energy) and pollutant (ammonia, methane, carbon-dioxide) emissions also change negatively from caged to non-cage housing systems, which causes a significant environmental impact. In a review article [98], the authors concluded that concentrations of ammonia gas are commonly high in aviaries and floor housing systems in which manure is not regularly removed. Thus, manure management is a key point concerning the layer house 
environment. In addition to harmful gas emission, particulate matter concentration is also higher in the non-cage systems.

Table 4. Research findings related to environmental issues of egg production in different housing systems.

\begin{tabular}{|c|c|}
\hline Studies & Main Findings \\
\hline Whyte (2002) [87] & $\begin{array}{l}\text { Exposure to particulate matter and ammonia concentration is higher } \\
\text { in B than in cage systems. }\end{array}$ \\
\hline Bessei et al. (2011) [88] & $\begin{array}{l}\text { The resource use and harmful gas emission per hen unit are steadily } \\
\text { growing from CC, through small group housing to B. }\end{array}$ \\
\hline Xin et al. (2011) [89] & $\begin{array}{l}\text { The treatment or presence of hen manure may pose significant } \\
\text { environmental load on the quality of air and water. In addition, } \\
\text { processing the manure has a relatively high energy demand. The air } \\
\text { quality (ammonia and dust) is usually lower in non-caged systems } \\
\text { than in cage housing. The resources use of egg production (feed, } \\
\text { energy and land) is less efficient in non-caged systems than in cage } \\
\text { housing, which leads to a larger carbon footprint. }\end{array}$ \\
\hline Dekker et al. (2011) [90] & $\begin{array}{l}\text { Based on an LCA analysis, it is projected that a ban on CC in the } \\
\text { European Union increases the global warming potential, } \\
\text { land occupation and acidification potential per kg of egg produced. } \\
\text { Resource use and emissions change negatively from cage housing to } \\
\text { non-cage systems. Of non-cage technologies, O systems have the } \\
\text { lowest global warming potential, energy use, fossil phosphorus use, } \\
\text { and nitrogen and phosphorus surplus, whereas land occupation and } \\
\text { nitrogen and phosphorus deficit are lowest for B systems. }\end{array}$ \\
\hline Shepherd et al. (2015) [91] & $\begin{array}{l}\text { The highest house-level ammonia emissions were observed in the } \\
\text { AV housing, followed by CC and EC. House-level methane } \\
\text { emissions were similar for all houses. The particulate matter } \\
\text { concentration was the highest in the AV housing, while similar } \\
\text { results were obtained in the CC and EC. The manure storage } \\
\text { accounts for } 60-70 \% \text { of the farm's ammonia output. }\end{array}$ \\
\hline Zhao et al. (2015) [92] & $\begin{array}{l}\text { Comparing the CC, EC and AV housing systems, air quality } \\
\text { (ammonia and particulate matter concentration) is the worst in the } \\
\text { AV housing system. }\end{array}$ \\
\hline van Asselt et al. (2015) [93] & $\begin{array}{l}\text { In the Netherlands, comparing the } \mathrm{EC}, \mathrm{AV}, \mathrm{FR} \text { and } \mathrm{O} \text { systems using a } \\
\text { scoring method, EC was the best system according to the } \\
\text { environmental dimension of sustainability. }\end{array}$ \\
\hline Pelletier (2017) [94] & $\begin{array}{l}\text { Among five housing technologies considered (CC, EC, free run, } \\
\text { FR, O), both the life cycle inventory and impact assessment results } \\
\text { suggested quite similar levels of performance between the } \\
\text { non-organic systems. In case of O production, lower research use } \\
\text { and emission intensity was found. }\end{array}$ \\
\hline
\end{tabular}

Conventional cage (CC), enriched cage (EC), aviary (AV), barn (B), free-range (FR), organic (O).

\subsection{Animal Welfare, Animal Health and Food Safety Issues}

Higher concentrations of particulate matter and harmful gas exposure in some housing systems, as described in the previous subchapter, could play a significant role in the development and incidence of respiratory diseases in birds [98], which is particularly important from an animal health point of view. It should also be mentioned that emissions of harmful gases, as well as high concentrations of particulate matter, pose a significant health risk to human resources. The impact of housing technologies on the health and safety of workers has been studied in only a few publications. In one of these works, Whyte [87] found that workers in barn systems are exposed to more dust and higher ammonia concentrations than people working in caged housing systems. Ochs et al. [99] pointed out that consumers do not recognize the threat of negative impacts on worker health and safety in alternative housing systems, as opposed to conventional cages. 
The researchers working on the project LayWel [35] concluded that, with the exception of conventional cages, all systems have the potential to provide satisfactory welfare for laying hens. However, maximizing this potential in practice is hindered by several factors, including management, group size, use of certain medical treatments, climate, feed, housing design, beak trim, as well as different responses by different genotypes and interacting effects $[35,100]$. Several animal welfare, animal health and food safety factors were evaluated in different studies to compare different housing systems (Table 5). Research findings related to animal welfare, animal health and food safety issues among the housing systems are listed in Table 6.

Table 5. Animal welfare, animal health and food safety factors in different housing systems and different studies.

\begin{tabular}{|c|c|c|c|c|c|c|c|c|c|}
\hline \multirow{2}{*}{ Studies } & \multirow{2}{*}{$\begin{array}{l}\text { Analyzed Housing } \\
\text { System }\end{array}$} & \multicolumn{8}{|c|}{ Evaluated Animal Welfare, Animal Health and Food Safety Factors } \\
\hline & & H/F/B & $\mathrm{I} / \mathrm{C}$ & $\mathrm{D} / \mathrm{P}$ & $\mathrm{FP} / \mathrm{C}$ & $\mathbf{M}$ & PP & MO/AB & $\mathbf{D} / \mathbf{R}$ \\
\hline Tauson (2002) [101] & $\mathrm{EC}, \mathrm{AV}$ & $\sqrt{ }$ & - & - & $\sqrt{ }$ & - & - & - & - \\
\hline Tauson (2005) [100] & $\mathrm{CC}, \mathrm{EC}, \mathrm{AV}, \mathrm{B}, \mathrm{FR}, \mathrm{O}$ & $\sqrt{ }$ & $\sqrt{ }$ & $\sqrt{ }$ & $\sqrt{ }$ & $\sqrt{ }$ & - & - & - \\
\hline Rodenburg et al. (2008) [103] & $\mathrm{EC}, \mathrm{AV} / \mathrm{B}$ & $\sqrt{ }$ & $\sqrt{ }$ & - & - & $\sqrt{ }$ & - & - & - \\
\hline de Reu et al. (2008) [104] & $\mathrm{CC}, \mathrm{EC}, \mathrm{AV}$ & - & - & - & - & - & - & $\sqrt{ }$ & - \\
\hline Bessei et al. (2011) [88] & $\mathrm{CC}, \mathrm{EC}, \mathrm{AV}, \mathrm{B}, \mathrm{FR}$ & $\sqrt{ }$ & $\sqrt{ }$ & $\sqrt{ }$ & $\sqrt{ }$ & - & - & - & - \\
\hline Lay et al. (2011) [107] & $\mathrm{CC}, \mathrm{EC}, \mathrm{AV} / \mathrm{B}, \mathrm{FR}$ & $\sqrt{ }$ & $\sqrt{ }$ & $\sqrt{ }$ & - & - & $\sqrt{ }$ & - & - \\
\hline de Vylder (2011) [108] & $\mathrm{CC}, \mathrm{EC}, \mathrm{AV}, \mathrm{B}$ & - & - & - & - & - & - & $\sqrt{ }$ & - \\
\hline Holt et al. (2011) [109] & $\mathrm{EC}, \mathrm{AV}, \mathrm{B}, \mathrm{FR}, \mathrm{O}$ & - & - & - & - & - & - & $\sqrt{ }$ & $\sqrt{ }$ \\
\hline Englmaierová et al. (2014) [60] & $\mathrm{CC}, \mathrm{EC}, \mathrm{AV}, \mathrm{B}$ & - & - & - & - & - & - & $\sqrt{ }$ & - \\
\hline Parisi et al. (2015) [110] & CC, FR & - & - & - & - & - & - & $\sqrt{ }$ & - \\
\hline Zhao et al. (2016) [113] & $\mathrm{CC}, \mathrm{EC}, \mathrm{AV}$ & - & - & - & - & - & - & $\sqrt{ }$ & - \\
\hline Stadig et al. (2016) [114] & $\mathrm{CC}, \mathrm{EC}, \mathrm{AV}, \mathrm{B}, \mathrm{FR}$ & $\sqrt{ }$ & $\sqrt{ }$ & $\sqrt{ }$ & $\sqrt{ }$ & $\sqrt{ }$ & - & - & - \\
\hline Hatcher and Jones (2017) [115] & cage, non-cage & $\sqrt{ }$ & $\sqrt{ }$ & $\sqrt{ }$ & $\sqrt{ }$ & - & - & - & - \\
\hline Galvão et al. (2018) [116] & CC, FR & - & - & - & - & - & - & $\sqrt{ }$ & - \\
\hline Vlčkova et al. (2018) [57] & $\mathrm{EC}, \mathrm{FR}$ & - & - & - & - & - & - & $\sqrt{ }$ & - \\
\hline Gast et al. (2019) [117] & $\mathrm{CC}, \mathrm{EC}$ & - & - & - & - & - & - & $\sqrt{ }$ & - \\
\hline Fulton (2019) [118] & $\mathrm{CC}, \mathrm{EC}, \mathrm{AV}$ & - & $\sqrt{ }$ & $\sqrt{ }$ & - & $\sqrt{ }$ & - & - & - \\
\hline
\end{tabular}

Conventional cage (CC), enriched cage (EC), aviary (AV), barn (B), free-range (FR), organic (O), housing, feeding and behavior $(\mathrm{H} / \mathrm{F} / \mathrm{B})$, injuries and condition $(\mathrm{I} / \mathrm{C})$, disease and parasitic $(\mathrm{D} / \mathrm{P})$, feather pecking and cannibalism $(\mathrm{FP} / \mathrm{C})$, mortality $(\mathrm{M})$, physiological parameters $(\mathrm{PP})$, microorganisms and airborne bacteria $(\mathrm{MO} / \mathrm{AB})$, dioxin and residues $(\mathrm{D} / \mathrm{R})$.

Table 6. Research findings related to animal welfare, animal health and food safety issues of egg production in different housing systems.

\begin{tabular}{cl}
\hline \multicolumn{1}{c}{ Studies } & \multicolumn{1}{c}{ Main Findings } \\
\hline Kijlstra (2004) [102] & The dioxin level is higher in eggs from FR and O housing than in caged eggs. \\
\hline Tauson (2005) [100] & $\begin{array}{l}\text { The main issues related to housing in larger groups: misplaced eggs, increased feed intake, } \\
\text { air quality (ammonia and dust levels), catching of spent hens, parasitic infection and } \\
\text { feather pecking. }\end{array}$ \\
\hline Rodenburg et al. (2008) [103] & $\begin{array}{l}\text { Birds are more active and their bones are stronger in non-cage housing than in EC. } \\
\text { The mortality rate, the frequency of bone fractures and the particulate matter concentration in } \\
\text { the air are lower in the case of EC. }\end{array}$ \\
\hline Vučemilo et al. (2010) [105] & $\begin{array}{l}\text { Alternative production systems are more favorable from the aspect of animal welfare and } \\
\text { behavioral requirements; however, they are dissatisfactory in terms of pollutants in the air and } \\
\text { hygiene, as they can represent a greater risk of horizontal contamination of the egg content. }\end{array}$ \\
\hline Sherwin et al. (2010) [106] & $\begin{array}{l}\text { Hens in B systems have the highest prevalence of old fractures, emaciation, poor plumage } \\
\text { condition, abnormal egg calcification, and the highest corticosterone. } \\
\text { Vent pecking was most common in FR flocks. The lowest prevalence of problems occurred in } \\
\text { hens in EC. }\end{array}$ \\
\hline
\end{tabular}


Table 6. Cont.

\begin{tabular}{|c|c|}
\hline Studies & Main Findings \\
\hline Bessei et al. (2011) [88] & $\begin{array}{l}\text { In B housing, the litter makes it possible for birds to bathe in dust and to peck in the dirt; } \\
\text { however, intestinal parasites are a threat. Increasing the group size in EC and B increases space, } \\
\text { which possibly leads to increased risk of bone fracture, feather pecking and cannibalism. }\end{array}$ \\
\hline Lay et al. (2011) [107] & $\begin{array}{l}\text { Mortality is generally lower in EC than in CC, and mortality can reach unacceptably high } \\
\text { levels in non-cage systems. EC may reduce the risk of bone breakage compared with CC or } \\
\text { non-cage systems. Hens in CC and EC have less bumblefoot and footpad dermatitis than more } \\
\text { extensively housed hens, but claw health is worse in CC than in all other systems. }\end{array}$ \\
\hline de Vylder (2011) [108] & $\begin{array}{l}\text { Increased bird-to-bird Salmonella Enteritidis transmission was detected in the AV and floor } \\
\text { system compared with cage systems. Contamination with Salmonella Enteritidis is more } \\
\text { common in eggs produced in AV, compared to cage systems and } \mathrm{B} \text {. }\end{array}$ \\
\hline Englmaierová et al. (2014) [60] & $\begin{array}{l}\text { The bacterial contamination of the eggshell fluctuates more in alternative housing systems } \\
\text { than in the case of the cage. }\end{array}$ \\
\hline Parisi et al. (2015) [110] & $\begin{array}{l}\text { FR eggs have greater microbiological contamination on the eggshell surface than eggs } \\
\text { produced in CC. }\end{array}$ \\
\hline Jones et al. (2015) [111] & $\begin{array}{l}\text { Particulate matter also affects the microbiology of the environment and eggs. } \\
\text { In non-cage systems, floor eggs have the greatest opportunity for exposure to high levels of } \\
\text { microorganisms and human pathogens. } \\
\text { During the management of housing systems, it is important to reduce and control the amount } \\
\text { of aerobes and coliforms, as well as the level of Salmonella and Campylobacter spp. in the } \\
\text { B system. }\end{array}$ \\
\hline Cotter (2015) [112] & Physiological measures did not show differences in stress between CC, EC and AV systems. \\
\hline van Asselt et al. (2015) [93] & $\begin{array}{l}\text { In the Netherlands, comparing the EC, } \mathrm{AV}, \mathrm{FR} \text { and } \mathrm{O} \text { systems using a scoring method, FR was } \\
\text { the best system according to the social dimension (food safety, animal welfare, and human } \\
\text { welfare) of sustainability. }\end{array}$ \\
\hline Zhao et al. (2016) [113] & $\begin{array}{l}\text { Based on the comparison of the CC, EC and AV housing systems, the highest airborne total } \\
\text { bacteria concentrations were observed in the AV system. However, airborne total bacteria } \\
\text { concentrations were higher in all three housing systems than the level recommended for the } \\
\text { human environment. }\end{array}$ \\
\hline Stadig et al. (2016) [114] & $\begin{array}{l}\text { Belgian egg farmers currently using cage systems were more satisfied with hen health than } \\
\text { farmers with non-cage systems. } \\
\text { According to Belgian farmers who shifted to non-cage systems from CC, feather pecking, } \\
\text { cannibalism, smothering and mortality were perceived to be higher in non-cage systems } \\
\text { compared to CC. }\end{array}$ \\
\hline Hatcher and Jones (2017) [115] & $\begin{array}{l}\text { The risk of the emergence and spreading of infectious diseases, as well as feather pecking, is } \\
\text { the lowest in non-cage systems. }\end{array}$ \\
\hline Galvão et al. (2018) [116] & CC systems have better hygiene and sanitary status than FR systems. \\
\hline Vlčkova et al. (2018) [57] & $\begin{array}{l}\text { The numbers of Escherichia coli and Enterococcus and the total number of microorganisms } \\
\text { were higher in FR eggs compared to EC eggs. }\end{array}$ \\
\hline Gast et al. (2019) [117] & $\begin{array}{l}\text { S. Enteritidis deposition inside eggs can vary between genetic lines of infected laying hens, } \\
\text { but housing these hens in two different systems did not affect the production of contaminated } \\
\text { eggs. }\end{array}$ \\
\hline Fulton (2019) [118] & $\begin{array}{l}\text { The mortality, keel bone fractures and other skeletal abnormalities were greatest for AV } \\
\text { compared with CC and EC. } \\
\text { EC housing is better for the health and welfare of layers than CC or AV housing. }\end{array}$ \\
\hline
\end{tabular}

Conventional cage (CC), enriched cage (EC), aviary (AV), barn (B), free-range (FR), organic (O).

Despite the fact that some animal welfare organizations and consumers consider non-cage systems to serve the purpose of animal welfare at all times as opposed to caged housing [35,47], the greater freedom of mobility achieved by increasing the group size increases the risk of bone fractures, as well as feather pinching and cannibalism [88,100,103,118]. A study [119] which analyzed the effect of keel fracture on production parameters found that this injury caused changes in the behavior of laying hens and reduced animal welfare, production performance, feed intake, and eggshell quality. A survey among Belgian producers [114] revealed that health- and production-related parameters are considered to be more important by producers for hen welfare as compared to behavior-related parameters. A survey [120] focusing on consumer preferences in the U.S. revealed that consumers consider less hen stress, more natural hen behavior, as well as the improved health and welfare of workers to be important. If housing systems are weighted based on consumer preference for animal 
and worker welfare characteristics, the preferred system is the enriched housing system [120]. Hartcher and Jones [115] also agree with these findings, highlighting that furnished cages retain the benefits of conventional cages in terms of hygiene and efficiency of production, and offer some benefits of non-cage systems. Moreover, they state that animal welfare in non-cage systems is currently highly inconsistent, and needs to be addressed by management practices, genetic selection, further research, and appropriate design and maintenance of the housing environment.

The mortality rate may be higher for aviary housing technology compared to other systems, mainly due to hypocalcaemia, ventilation, cloacal prolapse, foot disease, and cold or other diseases [121]. Comparing the furnished cages and aviary systems, Tauson [101] states that birds in both systems may show favorable production results, but aviaries are less predictable due to irregular outbreaks of flock cannibalism, especially in non-beak-trimmed birds.

In addition, Lay et al. [107] state that certain diseases, mainly caused by parasites, may occur more frequently in non-cage systems. As a result, veterinary interventions are more frequent and the number of veterinary drugs and vaccines used is higher [100]. As a consequence of more frequent veterinary interventions, Cepero and Hernándiz [53] suggest that the risk of residues of antimicrobials, anthelmintics and various anticoccidials may be higher for eggs produced in non-cage housing systems. Several studies $[57,60,104,105,110,116]$ also confirmed this finding and found that housing technologies significantly affect the number of bacteria on the surface of eggs and the level of microbial contaminants. In the case of conventional and enriched cage systems, eggshell contamination values in terms of both total bacterial counts and Escherichia coli are significantly lower compared to eggs from alternative technologies (aviary, barn), and the highest contamination was found in the case of barn housing. A review article [122] concluded that, when moving from cages to non-cage systems, the prevalence of Salmonella in laying hens increases. Parisi et al. [110] also found that free-range eggs, where hens have more contact with eggs after oviposition, have greater microbiological contamination on the eggshell surface than eggs produced in conventional cage systems. These phenomena pose a much greater risk to human health and consumers are likely to be unaware of these threats in many cases. However, Jones et al. [123] highlight that hen strain has an effect on egg microbial levels for various housing systems, i.e., egg safety should be considered when making hen strain selections for each housing system. In addition, the management of housing systems has a significant role in controlling the microbial contamination level of eggs [111].

The most common chemical contamination of eggs, i.e., increased levels of dioxin-like compounds, is identified with free-range and organic housing technologies [109]. Several previous studies $[102,109,124]$ examined dioxin levels in eggs. Based on the obtained results, experts have concluded that dioxin levels in products from organic farming were higher, exceeding the permissible value in many cases. The reason for this phenomenon may be partly due to the fact that, in organic farming, laying hens may be exposed to sources of dioxins other than feed, in contrast to cage systems. According to de Vries et al. [124], possible soil contamination, and the consumption of various plants and insects may increase the dioxin content of eggs. For this reason, in areas involved in organic farming, monitoring the level of soil contamination requires increased attention.

\subsection{Production Efficiency and Economic Issues}

Modern egg production is a capital-intensive activity that requires relatively large facilities and, therefore, long-term investment [99]. In the EU, the transition to enriched cage housing has entailed significant additional costs for participants in the sector, and egg producers must comply with a number of environmental, animal welfare and food safety legislations. The additional costs of complying with EU standards were estimated to account for about 16\% of production costs in 2017 [125], which puts EU producers at a significant international competitive disadvantage.

In addition to the additional costs associated with establishing alternative systems compared to traditional housing technologies [126], production costs are also higher, as production efficiency deteriorates in these systems (reduced egg production, lower stocking density, increased specific labor 
use, increased specific feed consumption, increased energy use, etc.) [88,90]. The results of Tauson [100] showed increased feed intake and mislaid eggs in non-cage systems, especially in litter. The findings obtained by other studies [60,127-130] also demonstrated that feed consumption is significantly higher in non-cage systems and thus the feed conversion ratio is worse than in conventional and enriched cage systems. In addition, Philippe et al. [131] reported lower laying rates and a high proportion of mislaid eggs in aviaries. Among other indicators, a decrease in the efficiency of labor use in non-cage systems was highlighted by Stadig et al. [114]. Certain studies [56,66,75] demonstrated that housing systems (cage vs. barn/organic) had no effect on egg production. In fact, in a small-scale study [130] egg production per hen per day was found to be higher in the free-range system, but it was similar in conventional cage and enriched cage systems. In an industrial experiment [132], the best production efficiency (egg production and feed conversion rate) was found in an enriched cage system compared to conventional cage and barn systems. In addition to the fact that higher feed conversion increases the average cost as feed costs account for a significant share of production costs, it also indirectly raises environmental and related sustainability issues, as an increased feed demand leads to higher resource use in feed production (arable land, water, chemicals, fossil resources, etc.).

Several studies $[125,126,133-136]$ confirm that the caged housing system is the most economical method of egg production. The average cost is different in caged and non-cage systems, and the production costs of eggs in enriched cages and non-cage systems may be higher by about $6-13 \%$ and $21-100 \%$, respectively, compared to conventional cages (Table 7). In addition to alternative housing methods, organic housing is becoming increasingly popular in Europe, despite the fact that it is much more expensive to produce eggs using this method due to higher feed consumption or lower productivity [137].

Table 7. Average cost in different housing systems.

\begin{tabular}{ccccccc}
\hline & \multicolumn{7}{c}{ Average Cost (\%) in Different Studies } \\
\cline { 2 - 7 } Housing & $\begin{array}{c}\text { Netherlands } \\
\text { Systems }\end{array}$ & USA & USA & France & Hungary & EU \\
& $\mathbf{( 2 0 0 7 - 2 0 0 8 )}$ & $\mathbf{( 2 0 1 1 )}$ & $\mathbf{( 2 0 1 1 )}$ & $\mathbf{( 2 0 1 2 )}$ & $\mathbf{( 2 0 1 2 - 2 0 1 5 )}$ & $\mathbf{( 2 0 1 5 , 2 0 1 7 )}$ \\
& {$[\mathbf{9 0 ]}$} & {$[\mathbf{1 2 6}]$} & {$[133]$} & {$[134]$} & {$[135]$} & {$[\mathbf{1 2 5 , 1 3 6 ]}$} \\
\hline Conventional cage & 100 & 100 & 100 & 100 & no data & 100 \\
Furnished cage & no data & no data & 113 & no data & 100 & 106 \\
Barn/aviary & $112-115$ & 140 & 136 & 113 & 139 & 123 \\
Free-range & $115-117$ & no data & no data & 128 & no data & no data \\
Organic & 185 & no data & no data & 213 & no data & no data \\
\hline
\end{tabular}

In addition to production cost, sales price is also an important economic issue. Rising production costs also mean that the differences between housing systems must be reflected in sales prices in order for the production process to be profitable. For this reason, it is important to know whether consumers in the given country/region are able or willing to pay a higher price for eggs produced in alternative housing systems before retail chains decide to show preference to eggs from non-cage housing systems. If a certain proportion of consumers are unwilling to pay more for eggs produced in alternative housing systems, it may lead to a decrease in turnover in stores, which could once again put their management in a difficult situation, thereby affecting producers as well.

With respect to consumer preferences, there are differences between regions and countries; moreover, these preferences are changing over time. According to a recent Polish study [47], the heterogeneity within the sociodemographic and socioeconomic characteristics confirms that niche markets for products produced with higher animal welfare standards do exist. A study [138] focused on consumer habits in British Columbia, Canada, also shows that the market is heterogeneous, and even though the number of consumers buying eggs from non-cage systems is increasing, a significant proportion of consumers (less educated, older, price sensitive, major chain store buyers, store flyer users, and those having less concern regarding animal welfare issues) are disinterested in how eggs 
are produced and decide which eggs to buy mostly based on their price. Two other studies from the USA $[139,140]$ similarly highlight that most consumers are not willing to pay significantly higher prices for non-caged and organic attributes. In addition, price-conscious consumers, if accepting higher prices, are more likely to require explicit justification of returns in quality [141]. Another U.S. study [142] found that consumers place more weight on animal welfare issues than environmental issues in their egg-purchase decisions, but food cost remains one of the most important factors for over a third of them.

A recent European study [143] found that price is the most important attribute for Hungarian and Italian consumers, followed by the nutrition and health claim and the organic production labeling. In both countries, similar consumer groups ("Price Sensitive and Quality Optimizing Opportunist Consumers" and "Health Conscious Buyers") were identified. In Italy and Hungary, approximately $40-45 \%$ of the consumers are more interested in the affordability of food choices than in environmental and health consequences. Compared to this segment, health conscious buyers (46-49\%) are willing to pay a higher price premium for eggs with an organic label and nutrition claims [143].

An earlier Spanish study [43] also found that price is the most important attribute in determining consumer preferences and only some groups of consumers are willing to pay the premium necessary for alternative methods of production. A Norwegian survey [144] noted that there is a segment of consumers willing to pay a substantial premium for organic eggs, but this segment is limited in size. A UK study [145] highlights contradictions in consumer views especially relating to the subject of perceived benefits of different methods of production.

\section{Discussion and Conclusions}

The results presented in this systematic literature review have several limitations. The published results compare the properties of egg production in caged and non-caged systems. However, more research would be needed with the aim to study egg production in several different housings at the same time, thus ensuring that the study conditions (experiment size, duration, hybrid, feed, management, etc.) are the same. It was an additional limitation that some of the available literature, especially those focusing on consumer habits, could no longer be considered relevant (i.e., older than 5 years) as consumer trends were changing relatively rapidly and continuously. Therefore, no general conclusion can be drawn from the results of previous surveys. The research was further complicated by the fact that egg producers in different geographical locations use different housing methods and production conditions (management, feeding, genetic background, etc.), i.e., it is difficult to compare the results of research performed in different countries. The research report summarizing the results of the CSES project [29] also highlights that the generalization and comparison of the specific results of research carried out in a given country under given conditions should be treated with caution. Nevertheless, in order to achieve the set objectives, the authors tried to objectively examine the issues related to the housing technological effects of egg production. For this reason, it is one of the strengths of this study that it explores and compares the sustainability issues of different housing technologies, as well as the factors affecting consumer health and egg consumption with a multidisciplinary approach, as opposed to reviews focusing on a more specific topic (e.g., quality, food security).

In this study, consumer preferences were compared to the scientific findings (according to the fifth subaim of this study) which focused on quality, environmental and animal welfare, animal health, food safety, production efficiency, as well as the economic aspects of the different housing systems used in egg production. In many cases, consumer preferences are not in harmony with scientific facts and do not serve sustainability-related purposes. In the opinion of the authors, this phenomenon can also be explained by the fact that, when buying eggs, the majority of consumers do not have enough information about the differences between the various types of housing. In addition, according to a recent study from the U.S. [44], balanced and real information about egg production had a positive effect on consumer willingness to pay for conventional eggs compared to non-caged eggs. The results of Ochs et al. point out the potential public misunderstanding of the costs and benefits associated 
with the "cage-free" egg label [146]. Eggs from free-range and organic housing systems are commonly regarded as having a better taste and being yellower in color, and by choosing to buy eggs produced in this way, these consumers are convinced that they do something to protect their health, as well as animals. For this reason, the proportion of different housing systems varies depending on consumer needs. In order to provide the widest possible range of information on the differences between caged and non-cage housing systems to producers in the sector, as well as consumers, a number of studies have been carried out in recent years, mainly in Europe, to examine the effects of different housing systems on egg quality, nutrient content, the environment and the welfare of laying hens.

Regarding the first subaim of this study, several contradictory results can be found in the literature about the external and internal quality of eggs, due to the fact that the quality of table eggs is influenced by several production factors such as the age of the hen, genetics, feeding and housing systems. In addition, significant interactions of these factors may be found in most of the observed quality parameters. In general, it can be concluded that eggs produced in caged systems are heavier and the eggshell quality is better in most cases compared to non-cage systems. The majority of studies show that the yolk of free-range eggs was heavier and more intense in color, while higher levels of cholesterol and potassium were found in organic housing, and some parts of the eggs weighed less, and the eggshell had poorer fracture resistance than in caged-system eggs.

For the second subaim of this study, from an environmental point of view, it should be noted that ammonia, nitrous oxide and methane emissions, as well as particulate matter concentrations, are usually higher in the case of non-caged systems, and the demand for water and feed production is increasing. These factors pose a significant risk of developing respiratory diseases, they increase the environmental load and can also have a negative impact on worker health. In addition, concerning to the third subaim of this study, it has been confirmed that despite the fact that hens have more space and freedom, the mortality, the risk of bone fractures, as well as feather pecking and cannibalism is higher in non-cage systems than in enriched cage systems. Moreover, eggs produced in caged housing systems have lower rates of veterinary drug residues and microbial contaminants on their surface and contain lower levels of dioxin than products from non-caged housing technologies.

The fourth subaim of this review dealt with the production efficiency and economic questions. It has been shown that there is an increase in the average cost when comparing caged housing systems to non-caged technologies, in parallel with the deterioration of production efficiency, especially due to increasing feed and labor use. However, a significant proportion of consumers in heterogeneous markets (containing market segments of different characteristics) are not willing to pay the resulting increased sales prices. In this context, according to the authors' opinions, the price-sensitive consumer segment remains, although the cage-free egg market is increasing, even if its proportion varies from country to country. For this reason, it is important that the current anti-cage lobby and trend in the EU does not lead to a decision to permanently phase out the sale of enriched (EU-compliant) cage technology and eggs from enriched cage systems. This decision would result in the consumer segment, which does not choose eggs on the basis of animal welfare and other considerations of its purchase, being deprived of their choice/decision and the preferences of the consumer group that buys eggs from non-cage systems for the protection/welfare of the animals would be forced on them. Sustainable food choices must be affordable and able to meet the need of different segments of consumers [143] and it is important to serve heterogeneous preferences [144]. For this reason, a heterogeneous market should serve its consumers with differentiated products, including the difference between various housing technologies.

In light of the obtained research findings, it can be concluded that, although there is a growing demand for alternative, non-caged products as environmental and health awareness and animal welfare issues are becoming more popular, non-caged production is not the best solution for environmentally, socially and economically sustainable egg supply. The authors of this paper recommend decision-makers (policy-makers, non-governmental organizations, industry) to consider the objective information presented here, i.e., the advantages and disadvantages of each housing 
type from as many aspects of sustainability as possible when making future decisions on egg production technology. This topic requires a multidisciplinary approach as well as a high degree of communication with food system stakeholders to ensure that the research results contribute to informed decision-making [28]. It is an important message of this study for decision-makers that it is necessary to look at the possibility of cage-free production in terms of both environmental protection and sustainability, as previously only animal welfare was in focus. It is important that the decision to phase out cage systems takes into account not only the needs of a narrow consumer group, in whose preferences animal welfare plays a greater role, but also consumers for whom animal welfare is only a secondary consideration when buying eggs, and who usually decide based on the price. We recommend that the possibility of using enriched cage housing technology in egg production not be eliminated. Rather, the decision should be left to the market, instead of authorities deciding about permissible housing technologies on the basis of a lobbying activity. Moreover, the authors believe that future research should also focus on the effects of different feeds and genetic backgrounds on sustainable egg production and their interactions in relation to each housing technology. Moreover, experiments and developments would be needed to reduce and eliminate the current negative effects and disadvantages of the current non-cage technologies in relation to cage housing systems.

Author Contributions: Conceptualization, S.M. and L.S.; methodology, S.M. and L.S.; writing—original draft preparation, S.M. and L.S.; writing - review and editing, S.M. and L.S.; visualization, S.M. and L.S.; supervision, L.S. All authors have read and agreed to the published version of the manuscript.

Funding: The publication is supported by the Debrecen Venture Catapult Program, EFOP-3.6.1-16-2016-00022 project. The project is co-financed by the European Union and the European Social Fund.

Conflicts of Interest: The authors declare no conflict of interest.

\section{References}

1. Zampelas, A. Still questioning the association between egg consumption and the risk of cardiovascular diseases. Atherosclerosis 2012, 224, 318-319. [CrossRef] [PubMed]

2. Rong, Y.; Chen, L.; Zhu, T.; Song, Y.; Yu, M.; Shan, Z.; Sands, A.; Hu, F.B.; Liu, L. Egg consumption and risk of coronary heart disease and stroke: Dose-response meta-analysis of prospective cohort studies. Br. Med. J. 2013, 346, 8539-8551. [CrossRef] [PubMed]

3. Miranda, J.M.; Anton, X.; Redondo-Valbuena, C.; Roca-Saavedra, P.; Rodriguez, J.A.; Lamas, A.; Franco, C.M.; Cepeda, A. Egg and egg-derived foods: Effects on human health and use as functional foods. Nutrients 2015, 7, 706-729. [CrossRef] [PubMed]

4. Gray, J.; Griffin, B. Eggs and dietary cholesterol-Dispelling the myth. Nutr. Bull. 2009, 34, 66-70. [CrossRef]

5. Bertechini, A.G.; Mazzuco, H. The table egg: A review. Ciênc. Agrotec. 2013, 37, 115-122. [CrossRef]

6. Egg Nutrition Council. How Many Eggs? - Position Statement for Healthcare Professionals; UK, 2012; pp. 1-5. Available online: http://www.internationalegg.com/wp-content/uploads/2015/11/2013-46HowManyEggsJuly2012ENC.pdf (accessed on 8 September 2020).

7. U.S Department of Health; Human Services; U.S. Department of Agriculture. 2015-2020 Dietary Guidelines for Americans, 8th ed.; Washington, DC, USA, 2015; pp. 15-18. Available online: http://health.gov/dietaryguidelines/ 2015/guidelines/ (accessed on 8 September 2020).

8. Herron, K.L.; Fernandez, M.L. Are the current dietary guidelines regarding egg consumption appropriate? J. Nutr. 2004, 134, 187-190. [CrossRef]

9. Sparks, N.H.C. The hen's egg-Is its role in human nutrition changing? Worlds Poult. Sci. J. 2006, 62, 308-315. [CrossRef]

10. Ruxton, C.H.S.; Derbyshire, E.; Gibson, S. The nutritional properties and health benefits of eggs. Nutr. Food Sci. 2010, 40, 263-279. [CrossRef]

11. Szőllősi, L.; Molnár, S.; Molnár, G.; Horn, P.; Sütő, Z. A tojás mint alapvető és funkcionális élelmiszer táplálkozás-élettani jelentősége. Táplálkozásmarketing 2017, 4, 7-22. [CrossRef]

12. Perić, L.; Rodić, V.; Milošević, N. Production of poultry meat and eggs as functional food-Challenges and opportunities. Biotechnol. Anim. Husb. 2011, 27, 511-520. [CrossRef] 
13. McNamara, D.J. Cholesterol intake and plasma cholesterol: An update. J. Am. Coll. Nutr. 1997, 16, 530-534. [CrossRef]

14. Horn, P.; Sütő, Z. A világ baromfihús-termelése és az előállítás versenyképessége. Acta Agraria Kaposv. 2014, 18, 14-29.

15. International Egg Commission. Available online: https://www.internationalegg.com (accessed on 10 May 2020).

16. FAO. Database of Food and Agriculture Organization of the United Nations. Available online: http: //www.fao.org/faostat/en/ (accessed on 23 May 2020).

17. European Commission. EU Agricultural Outlook for Markets and Income, 2019-2030, Figures (Excel), European Commission, DG Agriculture and Rural Development: Brussels. Available online: https:/ec.europa.eu/info/ food-farming-fisheries/farming/facts-and-figures/markets/outlook/medium-term_en\#latestissue (accessed on 12 May 2020).

18. Windhorst, H.-W. Housing Systems in Laying Hen Husbandry-First Part. Zootecnia International. 4 July 2017. Available online: https://zootecnicainternational.com/featured/housing-systems-laying-hen-husbandry/\# (accessed on 2 July 2019).

19. Windhorst, H.-W. Housing Systems in Laying Hen Husbandry-Second Part. Zootecnia International, 4 July 2017. Available online: https://zootecnicainternational.com/poultry-facts/housing-systems-layinghen-husbandry-second-part/ (accessed on 2 July 2019).

20. LayWel. Description of Housing Systems for Laying Hens-Deliverable 2.3. Welfare Implications of Changes in Production Systems for Laying Hens, LayWel Project, Project No. SSPE-CT-2004-502315, 2006, pp. 1-21. Available online: https://www.laywel.eu/web/pdf/deliverable\%2023-2.pdf (accessed on 4 August 2020).

21. Zhao, Y.; Shepherd, T.A.; Swanson, J.C.; Mench, J.A.; Karcher, D.M.; Xin, H. Comparative evaluation of three egg production systems: Housing characteristics and management practices. Poult. Sci. 2015, 94, 475-484. [CrossRef] [PubMed]

22. European Commission. EU Market Situation for Eggs, 20 May 2020, European Commission, DG Agriculture and Rural Development, Committee for the Common Organisation of the Agricultural Markets: Brussels. Available online: https://ec.europa.eu/info/food-farming-fisheries/farming/facts-and-figures/markets/overviews/ market-overview-sector_en (accessed on 20 May 2020).

23. Schjøll, A.; Borgen, S.O.; Alfnes, F. Consumer Preference for Animal Welfare When Buying Eggs; National Institute for Consumer Research: Oslo, Norway, 2012; ISBN 978-82-7063-443-9. Available online: http://www.kore.no/ wp-content/uploads/2018/10/Consumer-preference-for-animal-welfare-when-buying-eggs.pdf (accessed on 22 April 2018).

24. Leenstra, F.R.; Maurer, V.; Galea, F.; Bestman, M.W.P.; Amsler, Z.; Visscher, J.; Vermeij, I.; van Krimpen, M.M. Laying hen performance in different production systems; why do they differ and how to close the gap? Results of discussions with groups of farmers in The Netherlands, Switzerland and France, benchmarking and model calculations. Eu. Poult. Sci. 2014, 78, 1-10. [CrossRef]

25. Mench, J.A.; Sumner, D.A.; Rosen-Molina, J.T. Sustainability of egg production in the United States-The policy and market context. Poult. Sci. 2011, 90, 229-240. [CrossRef] [PubMed]

26. Gunnarsson, S.; Arvidsson Segerkvist, K.; Göransson, L.; Hansson, H.; Sonesson, U. Systematic mapping of research on farm-level sustainability in egg and chicken meat production. Sustainability 2020, 12, 3033. [CrossRef]

27. Swanson, J.C.; Mench, J.A.; Karcher, D. The Coalition for Sustainable Egg Supply project: An introduction. Poult. Sci. 2015, 94, 473-474. [CrossRef]

28. Mench, J.A.; Swanson, J.C.; Arnot, C. The Coalition for Sustainable Egg Supply: A unique public-private partnership for conducting research on the sustainability of animal housing systems using a multistakeholder approach. J. Anim. Sci. 2016, 94, 1296-1308. [CrossRef]

29. Coalition for Sustainable Egg Supply. Final Research Result Report; The Centre for Food Integrity: Gladstone, MO, USA, 2015; Available online: https://www2.sustainableeggcoalition.org/final-results (accessed on 9 September 2020).

30. Guyonnet, V. Eggs and egg products: Consumers' attitudes, perceptions and behaviours. In Proceedings of the XXIV. World's Poultry Congress, Salvador, Bahia, Brazil, 5-9 August 2012; pp. 1-10. Available online: https:/pdfs.semanticscholar.org/a39b/43d2b89b66fc2bfe09257e7e965319ad70b1.pdf (accessed on 4 August 2020).

31. Grant, M.J.; Booth, A. A typology of reviews: An analysis of 14 review types and associated methodologies. Health Inf. Libr. J. 2009, 26, 91-108. [CrossRef] 
32. Boar, A.; Bastida, R.; Marimon, F. A Systematic Literature Review. Relationships between the Sharing Economy, Sustainability and Sustainable Development Goals. Sustainability 2020, 12, 6744. [CrossRef]

33. Blandford, D.; Bureau, J.C.; Fulponi, L.; Henson, S. Potential Implications of Animal Welfare Concerns and Public Policies in Industrialized Countries for International Trade. In Global Food Trade and Consumer Demand for Quality; Krissoff, B., Bohman, M., Caswell, J.A., Eds.; Springer: Boston, MA, USA, 2002; pp. 77-99. ISBN 978-1-4757-5329-5. [CrossRef]

34. Moura, D.J.; Nääs, I.A.; Pereira, D.F.; Silva, R.B.T.R.; Camargo, G.A. Animal welfare concepts and strategy for poultry production: A review. Braz. J. Poult. Sci. 2006, 8, 137-148. [CrossRef]

35. Blokhuis, H.J.; van Niekerk, T.F.; Bessei, W.; Elson, A.; Guemene, D.; Kjaer, J.B.; Levrino, G.A.M.; Nicol, C.J.; Tauson, R.; Weeks, C.A.; et al. The LayWel project: Welfare implications of changes in production systems for laying hens. Worlds Poult. Sci. J. 2007, 63, 101-114. [CrossRef]

36. Napolitano, F.; Girolami, A.; Braghieri, A. Consumer liking and willingness to pay for high welfare animal based products. Trends Food Sci. Tech. 2010, 21, 537-543. [CrossRef]

37. Schmidt, K. Concepts of Animal Welfare in Relation to Positions in Animal Ethics. Acta Biotheor. 2011, 59, 153-171. [CrossRef]

38. Spain, C.V.; Freund, D.; Mohan-Gibbons, H.; Meadow, R.G.; Beacham, L. Are they buying it? United States consumers' changing attitudes toward more humanely raised meat, eggs, and dairy. Animals 2018, 8, 128. [CrossRef]

39. Yu, Y.; Han, X.; Hu, G. Optimal production for manufacturers considering consumer environmental awareness and green subsidies. Int. J. Prod. Econ. 2016, 182, 397-408. [CrossRef]

40. Yang, H.; Chen, W. Retailer-driven carbon emission abatement with consumer environmental awareness and carbon tax: Revenue-sharing versus Cost-sharing. Omega 2018, 78, 179-191. [CrossRef]

41. Jensen, H.H.; Kesavan, T.; Johnson, S.R. Measuring the Impact of Health Awareness on Food Demand. Appl. Econ. Perspect. Policy 1992, 14, 299-312. [CrossRef]

42. Drescher, L.; Thiele, S.; Roosen, J.; Mensink, G.B. Consumer demand for healthy eating considering diversity-An economic approach for German individuals. Int. J. Consum. Stud. 2009, 33, 684-696. [CrossRef]

43. Mesías, F.J.; Martínez-Carrasco, F.; Martínez, J.M.; Gaspar, P. Functional and organic eggs as an alternative to conventional production: A conjoint analysis of consumers' preferences. J. Sci. Food Agric. 2010, 91, 532-538. [CrossRef]

44. Li, T.; Bernard, J.C.; Johnston, Z.A.; Messer, K.D.; Kaiser, H.M. Consumer preferences before and after a food safety scare: An experimental analysis of the 2010 egg recall. Food Policy 2017, 66, 25-34. [CrossRef]

45. Lopez-Galan, B.; Gracia, A.; Barreiro-Hurle, J. What comes first, origin or production method? An investigation into the relative importance of different attributes in the demand for eggs. Span. J. Agric. Res. 2013, 11, 305-315. [CrossRef]

46. Güney, O.I.; Giraldo, L. Consumers' attitudes and willingness to pay for organic eggs: A discrete choice experiment study in Turkey. Br. Food J. 2019, 122, 678-692. [CrossRef]

47. Żakowska-Biemans, S.; Tekień, A. Free range, organic? Polish consumers preferences regarding information on farming system and nutritional enhancement of eggs: A discrete choice based experiment. Sustainability 2017, 9, 1999. [CrossRef]

48. Rodić, V.; Perić, L.; Pavlovski, Z.; Milošević, N. Improving the poultry sector in Serbia: Major economic constraints and opportunities. Worlds Poult. Sci. J. 2010, 66, 241-250. [CrossRef]

49. Anderson, K.E. Comparison of fatty acid, cholesterol, and vitamin A and E composition in eggs from hens housed in conventional cage and range production facilities. Poult. Sci. 2011, 90, 1600-1608. [CrossRef]

50. Bray, H.J.; Ankeny, R.A. Happy Chickens Lay Tastier Eggs: Motivations for Buying Free-range Eggs in Australia. Anthrozoös 2017, 30, 213-226. [CrossRef]

51. Kralik, G.; Škrtić, Z.; Suchý, P.; Straková, E.; Gajčević, Z. Feeding fish oil and linseed oil to laying hens to increase the n-3 PUFA in egg yolk. Acta Vet. Brno 2008, 77, 561-568. [CrossRef]

52. Senbeta, E.K.; Zeleke, N.A.; Molla, Y.G. Attitudes and perceptions of consumers to chicken egg attributes in eastern Ethiopia. J. Anim. Vet. Adv. 2015, 5, 705-710. [CrossRef] 
53. Cepero, R.; Hernándiz, A. Effects of Housing Systems for Laying Hens on Egg Quality and Safety. In Proceedings of the XXII European Symposium on the Quality of Poultry Meat and XVI European Symposium on the Quality of Eggs and Egg Products, WPSA, Nantes, France, 11-13 May 2015. Available online: http://www.wpsa.com/index.php/publications/wpsa-proceedings/effects-of-housing-systems-forlaying-hens-on-egg-quality-and-safety-1/viewdocument/2081 (accessed on 15 July 2020).

54. Perić, L.; Đukić Stojčić, M.; Bjedov, S. Effect of production systems on quality and chemical composition of table eggs. Contemp. Agric. 2016, 65, 27-31. [CrossRef]

55. Yenice, G.; Kaynar, O.; Ileriturk, M.; Hira, F.; Hayirli, A. Quality of Eggs in Different Production Systems. Czech J. Food Sci. 2016, 34, 370-376. [CrossRef]

56. Zita, L.; Jenikova, M.; Hartloya, H. Effect of housing system on egg quality and the concentration of cholesterol in egg yolk and blood of hens of native resources of the Czech Republic and Slovakia. J. Appl. Poult. Res. 2018, 27, 380-388. [CrossRef]

57. Vlčková, J.; Tůmová, E.; Ketta, M.; Englmaierová, M.; Chodová, D. Effect of housing system and age of laying hens on eggshell quality, microbial contamination, and penetration of microorganisms into eggs. Czech J. Anim. Sci. 2018, 63, 51-60. [CrossRef]

58. Kraus, A.; Zita, L.; Krunt, O. The effect of different housing system on quality parameters of eggs in relationship to the age in brown egg-laying hens. Bulg. J. Agric. Sci. 2019, 25, 1246-1253.

59. Hidalgo, A.; Rossi, M.; Clerici, F.; Ratti, S. A market study on the quality characteristics of eggs from different housing systems. Food Chem. 2008, 106, 1031-1038. [CrossRef]

60. Englmaierová, M.; Tůmová, E.; Charvátová, V.; Skřivan, M. Effects of laying hens housing system on laying performance, egg quality characteristics, and egg microbial contamination. Czech. J. Anim. Sci. 2014, 59, 345-352. [CrossRef]

61. Galic, A.; Filipovic, D.; Janjecic, Z.; Bedekovic, D.; Kovacev, I.; Copec, K.; Pliestic, S. Physical and mechanical characteristics of Hisex Brown hen eggs from three different housing systems. S. Afr. J. Anim. Sci. 2019, 49, 468-476. [CrossRef]

62. Beardswort, P.M.; Hernandes, J.M. Yolk colour-An important egg quality attribute. Int. Poult. Prod. 2004, 12, 17-18.

63. Kralik, Z.; Radišić, Ž.; Grčević, M.; Kralik, G. Comparison of Table Eggs Quality Originating from Hens Kept in Different Housing Systems. XXI European Symposium on the Quality of Poultry Meat and XV European Symposium on the Quality of Eggs and Egg Products, WPSA, Bergamo, Italy, 15-19 September 2013. Available online: http://www.wpsa.com/index.php/publications/wpsa-proceedings/comparison-of-qualityof-table-eggs-produced-in-various-systems-of-keeping-laying-hens/viewdocument/1192 (accessed on 15 July 2020).

64. Minelli, G.; Sirri, F.; Folegatti, E.; Meluzzi, A.; Franchini, A. Egg quality traits of laying hens reared in organic and conventional systems. Ital. J. Anim. Sci. 2007, 6, 728-730. [CrossRef]

65. Matt, D.; Veromann, E.; Luik, A. Effect of housing systems on biochemical composition of chicken eggs. Agron. Res. 2009, 7, 662-667.

66. Küçükyılmaz, K.; Bozkurt, M.; Herken, E.N.; Çınar, M.; Çath, A.U.; Bintaş, E.; Çöven, F. Effects of rearing systems on performance, egg characteristics and immune response in two layer hen genotype. Asian-Australas J. Anim. Sci. 2012, 25, 559-568. [CrossRef] [PubMed]

67. Jones, D.R.; Karcher, D.M.; Abdo, Z. Effect of a commercial housing system on egg quality during extended storage. Poult. Sci. 2014, 93, 1282-1288. [CrossRef] [PubMed]

68. Samiullah, R.J.R.; Chousalkar, K.K. Effect of production system and flock age on egg quality and total bacterial load in commercial laying hens. J. Appl. Poult. Res. 2014, 23, 59-70. [CrossRef]

69. Yang, H.M.; Yang, Z.; Wang, W.; Wang, Z.Y.; Sun, H.N.; Ju, X.J.; Qi, X.M. Effects of different housing systems on visceral organs, serum biochemical proportions, immune performance and egg quality of laying hens. Eur. Poult. Sci. 2014, 78, 1-9. [CrossRef]

70. Ferrante, V.; Lolli, S.; Vezzoli, G.; Guidobono Cavalchini, L. Effects of two different rearing systems (organic and barn) on production performance, animal welfare traits and egg quality characteristics in laying hens. Ital. J. Anim. Sci. 2009, 8, 165-174. [CrossRef]

71. Yilmaz Dikmen, B.; Ipek, A.; Sahan, U.; Sözcü, A.; Baycan, S.C. Impact of different housing systems and age of layers on egg quality characteristics. Turk. J. Vet. Anim. Sci. 2017, 41, 77-84. [CrossRef] 
72. Sokołowicz, Z.; Krawczyk, J.; Dykiel, M. The effect of the type of alternative housing system, genotype and age of laying hens on egg quality. Ann. Anim. Sci. 2018, 18, 541-555. [CrossRef]

73. Sokołowicz, Z.; Krawczyk, J.; Dykiel, M. Effect of alternative housing system and hen genotype on egg quality characteristics. Emir. J. Food Agric. 2018, 30, 695-703. [CrossRef]

74. Vlčkova, J.; Tůmova, E.; Míková, K.; Englmaierová, M.; Okrouhlá, M.; Chodová, D. Changes in the quality of eggs during storage depending on the housing system and the age of hens. Poult. Sci. 2019, 98, 6187-6193. [CrossRef]

75. Ghanima, M.M.A.; Elsadek, M.F.; Taha, A.E.; El-Hack, M.E.A.; Alagawany, M.; Ahmed, B.M.; Elshafie, M.M.; El-Sabrout, K. Effect of housing system and rosemary and cinnamon essential oils on layers performance, egg quality, haematological traits, blood chemistry, immunity, and antioxidant. Animals 2020, 10, 245. [CrossRef]

76. Popova, T.; Petkov, E.; Ayasan, T.; Ignatova, M. Quality of Eggs from Layers Reared under Alternative and Conventional System. Braz. J. Poult. Sci. 2020, 22, 1172:1-1172:8. [CrossRef]

77. De Reu, K.; Rodenburg, T.B.; Grijspeerdt, K.; Messens, W.; Heyndrickx, M.; Tuyttens, F.A.M.; Sonck, B.; Zoons, J.; Herman, L. Bacteriological contamination, dirt, and cracks of eggshells in furnished cages and noncage systems for laying hens: An international on-farm comparison. Poult. Sci. 2009, 88, 2442-2448. [CrossRef] [PubMed]

78. Hooge, D.M. Bacillus subtilis spores improve Brown egg colour. World Poult. 2007, 23, 14-15.

79. Samiullah, S.; Roberts, J.R.; Chousalkar, K. Eggshell color in brown-egg laying hens-A review. Poult. Sci. 2015, 94, 2566-2575. [CrossRef]

80. Arthur, J.A.; O'Sullivan, N. Breeding chickens to meet egg quality needs. Int. Hatch. Pract. 2005, 19, 7-9.

81. Küçükyılmaz, K.; Bozkurt, M.; Yamaner, C.; Çınar, M.; Çatlı, A.U.; Konak, R. Effect of an organic and conventional rearing system on the mineral content of hen eggs. Food Chem. 2012, 132, 989-992. [CrossRef]

82. Karcher, D.M.; Jones, D.R.; Abdo, Z.; Zhao, Y.; Shepherd, T.A.; Xin, H. Impact of commercial housing systems and nutrient and energy intake on laying hen performance and egg quality parameters. Poult. Sci. 2015, 94, 485-501. [CrossRef]

83. Radu-Rusu, R.M.; Usturoi, M.G.; Leahu, A.; Amariei, S.; Radu-Rusu, C.G.; Vacaru-Opriş, I. Chemical features, cholesterol and energy content of table hen eggs from conventional and alternative farming systems. S. Afr. J. Anim. Sci. 2014, 44, 33-42. [CrossRef]

84. Bejaei, M.; Wiseman, K.; Cheng, K.M. Influences of demographic characteristics, attitudes, and preferences of consumers on table egg consumption in British Columbia, Canada. Poult. Sci. 2011, 90, 1088-1095. [CrossRef]

85. Bombik, E.; Lagowska, K.; Bednarczyk-Szurmak, M.; Rózewicz, M.; Janocha, A. Characterization of table eggs-producing organic farms in Lublin Voivodeship. Acta Sci. Pol. Zootechn. 2015, 14, 55-66.

86. Rahmani, D.; Kallas, Z.; Pappa, M.; Gil, J.M. Are consumers' egg preferences influenced by animal-welfare conditions and environmental impacts? Sustainability 2019, 11, 6218. [CrossRef]

87. Whyte, R.T. Occupational exposure of poultry stockmen in current barn systems for egg production in the United Kingdom. Br. Poult. Sci. 2002, 43, 364-373. [CrossRef]

88. Bessei, W. Az árutojás-termelés átállási gondjai. Baromfiágazat 2011, 11, 62-69.

89. Xin, H.; Gates, R.S.; Green, A.R.; Mitloehner, F.M.; Moore, P.A.; Wathes, C.M. Environmental impacts and sustainability of egg production systems. Poult. Sci. 2011, 90, 263-277. [CrossRef] [PubMed]

90. Dekker, S.E.M.; de Boer, I.J.M.; Vermeij, I.; Aarnink, A.J.A.; Groot Koerkamp, P.W.G. Ecological and economic evaluation of Dutch egg production systems. Livest. Sci. 2011, 139, 109-121. [CrossRef]

91. Shepherd, T.A.; Zhao, Y.; Li, H.; Stinn, J.P.; Hayes, M.D.; Xin, H. Environmental assessment of three egg production systems-Part II. Ammonia, greenhouse gas, and particulate matter emissions. Poult. Sci. 2015, 94, 534-543. [CrossRef]

92. Zhao, Y.; Shepherd, T.A.; Li, H.; Xin, H. Environmental assessment of three egg production systems-Part I: Monitoring system and indoor air quality. Poult. Sci. 2015, 94, 518-533. [CrossRef]

93. Van Asselt, E.D.; van Bussel, L.G.J.; van Horne, P.; van der Voet, H.; van der Heijden, G.W.A.M.; van der Fels-Klerx, H.J. Assessing the sustainability of egg production systems in The Netherlands. Poult. Sci. 2015, 94, 1742-1750. [CrossRef]

94. Pelletier, N. Life cycle assessment of Canadian egg products, with differentiation by hen housing system type. J. Clean. Prod. 2017, 152,167-180. [CrossRef] 
95. Abín, R.; Laca, A.; Laca, A.; Díaz, M. Environmental assesment of intensive egg production: A Spanish case study. J. Clean. Prod. 2018, 179, 160-168. [CrossRef]

96. Horn, P. Korunk fő fejlődési tendenciái az élelmiszertermelésben, különös tekintettel az állati termékekre. Gazdálkodás Sci. J. Agric. Econ. 2013, 57, 516-531. [CrossRef]

97. Fróna, D.; Szenderák, J.; Harangi-Rákos, M. The challenge of feeding the world. Sustainability 2019, 11, 5816. [CrossRef]

98. David, B.; Mejdell, C.; Michel, V.; Lund, V.; Moe, R.O. Air quality in alternative housing systems may have an impact on laying hen welfare. Part II-Ammonia. Animals 2015, 5, 886-896. [CrossRef] [PubMed]

99. Ochs, D.; Wolf, C.A.; Widmar, N.J.O.; Bir, C. Consumer perceptions of egg-laying hen housing systems. Poult. Sci. 2018, 97, 3390-3396. [CrossRef] [PubMed]

100. Tauson, R. Management and housing systems for layers-Effects on welfare and production. Worlds Poult. Sci. J. 2005, 61, 477-490. [CrossRef]

101. Tauson, R. Furnished cages and aviaries: Production and health. Worlds Poult. Sci. J. 2002, 58, 49-63. [CrossRef]

102. Kijlstra, A. The Role of Organic and Free Range Poultry Production Systems on the Dioxin Levels in Eggs. In Proceedings of the 3rd SAFO Workshop, Falenty, Poland, 16-18 September 2004; pp. 83-90. Available online: https://pdfs.semanticscholar.org/12b2/9a6b5e5092bf00009630a92bc588ce69f382.pdf (accessed on 15 July 2020).

103. Rodenburg, T.B.; Tuyttens, F.A.M.; de Reu, K.; Herman, L.; Zoons, J.; Sonck, B. Welfare assessment of laying hens in furnished cages and non-cage systems: An on-farm comparison. Anim. Welf. 2008, 17, 363-373.

104. De Reu, K.; Messens, W.; Heyndrickx, M.; Rodenburg, T.B.; Uyttendaele, M.; Herman, L. Bacterial contamination of table eggs and the influence of housing systems. Worlds Poult. Sci. J. 2008, 64, 5-19. [CrossRef]

105. Vučemilo, M.; Vinkovic, B.; Matkovic, K.; Štokovc, I.; Jakšic, S.; Radovic, S.; Granic, K.; Stubičan, D. The influence of housing systems on the air quality and bacterial eggshell contamination of table eggs. Czech J. Anim. Sci. 2010, 55, 243-249. [CrossRef]

106. Sherwin, C.M.; Richards, G.J.; Nicol, C.J. Comparison of the welfare of layer hens in 4 housing systems in the UK. Br. Poult. Sci. 2010, 51, 488-499. [CrossRef]

107. Lay, D.C.; Fulton, R.M.; Hester, P.Y.; Karcher, D.M.; Kjaer, J.B.; Mench, J.A.; Mullens, B.A.; Newberry, R.C.; Nicol, C.J.; O'Sullivan, N.P.; et al. Hen welfare in different housing systems. Poult. Sci. 2011, 90, 278-294. [CrossRef] [PubMed]

108. De Vylder, J.; Dewulf, J.; van Hoorebeke, S.; Pasmans, F.; Haesebrouck, F.; Ducatelle, R.; van Immerseel, F. Horizontal transmission of Salmonella enteritidis in groups of experimentally infected laying hens housed in different housing systems. Poult. Sci. 2011, 90, 1391-1396. [CrossRef] [PubMed]

109. Holt, P.S.; Davies, R.H.; Dewulf, J.; Gast, R.K.; Huwe, J.K.; Jones, D.R.; Waltman, D.; Willian, K.R. The impact of different housing systems on egg safety and quality. Poult. Sci. 2011, 90, 251-262. [CrossRef] [PubMed]

110. Parisi, M.A.; Northcutt, J.K.; Smith, D.P.; Steinberg, E.L.; Dawson, P.L. Microbiological contamination of shell eggs produced in conventional and free-range housing systems. Food Control 2015, 47, 161-165. [CrossRef]

111. Jones, D.R.; Cox, N.A.; Guard, J.; Fedorka-Cray, P.J.; Buhr, R.J.; Gast, R.K.; Abdo, Z.; Rigsby, L.L.; Plumblee, J.R.; Karcher, D.M.; et al. Microbiological impact of three commercial laying hen housing systems. Poult. Sci. 2015, 94, 544-551. [CrossRef]

112. Cotter, P.F. An examination of the utility of heterophil-lymphocyte ratios in assessing stress of caged hens. Poult. Sci. 2015, 94, 512-517. [CrossRef]

113. Zhao, Y.; Zhao, D.; Ma, H.; Liu, K.; Atilgan, A.; Xin, H. Environmental assessment of three egg production systems-Part III: Airborne bacteria concentrations and emissions. Poult. Sci. 2016, 95, 1473-1481. [CrossRef]

114. Stadig, L.M.; Ampe, B.A.; van Gansbeke, S.; van den Bogaert, T.; D’Haenens, E.; Heerkens, J.L.T.; Tuyttens, F.A.M. Survey of egg farmers regarding the ban on conventional cages in the EU and their opinion of alternative layer housing systems in Flanders, Belgium. Poult. Sci. 2016, 95, 715-725. [CrossRef]

115. Hartcher, K.M.; Jones, B. The welfare of layer hens in cage and cage-free housing systems. Worlds Poult. Sci. J. 2017, 73, 767-782. [CrossRef]

116. Galvão, J.A.; Biondo, A.W.; Possebon, F.S.; Spina, T.L.B.; Correia, L.B.N.; Zuim, C.V.; Guerra Filho, J.B.P.G.; Pantoja, J.C.F.; Pinto, J.P.d.A.N. Microbiological vulnerability of eggs and environmental conditions in conventional and free-range housing systems. Semin. Cienc. Agrar. 2018, 39, 133-142. [CrossRef] 
117. Gast, R.; Regmi, P.; Guraya, R.; Jones, D.; Anderson, K.E.; Karcher, D.M. Contamination of eggs by Salmonella Enteritidis in experimentally infected laying hens of four commercial genetic lines in conventional cages and enriched colony housing. Poult. Sci. 2019, 98, 5023-5027. [CrossRef] [PubMed]

118. Fulton, R.M. Health of commercial egg laying chickens in different housing systems. Avian Dis. 2019, 63, 420-426. [CrossRef]

119. Wei, H.; Bi, Y.; Xin, H.; Pan, L.; Liu, R.; Li, X.; Li, J.; Zhang, R.; Bao, J. Keel fracture changed the behavior and reduced the welfare, production performance, and egg quality in laying hens housed individually in furnished cages. Poult. Sci. 2020, 99, 3334-3342. [CrossRef] [PubMed]

120. Ochs, D.; Wolf, C.A.; Widmar, N.J.; Bir, C. Is there a "cage-free" lunch in U.S. egg production? Public views of laying-hen housing attributes. J. Agric. Resour. Econ. 2019, 44, 345-361. [CrossRef]

121. Nernberg, L. Cost Differential between Cage-Free Laying Systems. Poultry World, 3 August 2018. Available online: https://www.poultryworld.net/Eggs/Articles/2018/8/Cost-differential-between-cage-freelaying-systems-317512E/ (accessed on 15 July 2020).

122. Van Hoorebeke, S.; van Immerseel, F.; Haesebrouck, F.; Ducatelle, R.; Dewulf, J. The influence of the housing system on Salmonella infections in laying hens: A review. Zoonoses Public Health 2011, 58, 304-311. [CrossRef]

123. Jones, D.R.; Anderson, K.E. Housing system and laying hen strain impacts on egg microbiology. Poult. Sci. 2013, 92, 2221-2225. [CrossRef]

124. De Vries, M.; Kwakkel, R.P.; Kijlstra, A. Dioxins in organic eggs: A review. NJAS-Wagen. J. Life Sci. 2006, 54, 207-221. [CrossRef]

125. Van Horne, P.L.M. Competitiveness the EU Egg Sector, Base Year 2017: International Comparison of Production Costs; Report 2019-008; Wageningen Economic Research: Wageningen, The Netherlands, 2019; pp. 9-15. [CrossRef]

126. Sumner, D.A.; Gow, H.; Hayes, D.; Matthews, W.; Norwood, B.; Rosen-Molina, J.T.; Thurman, W. Economic and market issues on the sustainability of egg production in the United States: Analysis of alternative production systems. Poult. Sci. 2011, 90, 241-250. [CrossRef]

127. Aerni, V.; Brinkhof, M.W.G.; Wechsler, B.; Oester, H.; Fröhlich, E. Productivity and mortality of laying hens in aviaries: A systematic review. Worlds Poult. Sci. J. 2005, 61, 131-143. [CrossRef]

128. Sumner, D.A.; Matthews, W.A.; Mench, J.A.; Rosen-Molina, J.T. The economics of regulations on hen housing in California. J. Agric. Appl. Econ. 2010, 42, 429-438. [CrossRef]

129. Sekeroglu, A.; Sarica, M.; Demir, E.; Ulutas, Z.; Tilki, M.; Saatci, M.; Omed, H. Effect of different housing systems on some performance traits and egg qualities of laying hens. J. Anim. Vet. Adv. 2010, 9, 1739-1744. [CrossRef]

130. Yilmaz Dikmen, B.; Ípek, A.; Şahan, Ü.; Petek, M.; Sözcü, A. Egg production and welfare of laying hens kept in different housing systems (conventional, enriched cage, and free range). Poult. Sci. 2016, 95, 1564-1572. [CrossRef] [PubMed]

131. Philippe, F.X.; Mahmoudi, Y.; Cinq-Mars, D.; Lefrançois, M.; Moula, N.; Palacios, J.; Pelletier, F.; Godbout, S. Comparison of egg production, quality and composition in three production systems for laying hens. Livest. Sci. 2020, 232, 103917:1-103917:10. [CrossRef]

132. Gerzilov, V.; Datkova, V.; Mihaylova, S.; Bozakova, N. Effect of poultry housing systemson egg production. Bulg. J. Agric. Sci. 2012, 18, 953-957.

133. Matthews, W.A.; Sumner, D.A. Effects of housing system on the costs of commercial egg production. Poult. Sci. 2015, 94, 552-557. [CrossRef]

134. Chenut, R. Production cost of eggs in France. In Proceedings of the 4th European Round Table on Poultry Economics, Working Group 1 (Economics and Marketing) of the World Poultry Science Association (WPSA), Zollikofen, Switzerland, 24-25 October 2013.

135. Szőllősi, L.; Szúcs, I.; Huzsvai, L.; Molnár, S. Economic issues of Hungarian table egg production in different housing systems, farm sizes and production levels. J. Cent. Eur. Agric. 2019, 20, 995-1008. [CrossRef]

136. Van Horne, P.L.M.; Bondt, N. Competitiveness of the EU Egg Sector, Base Year 2015: International Comparison of Production Costs; Report 2017-062; Wageningen Economic Research: Wageningen, The Netherlands, 2017; pp. 11-15. [CrossRef]

137. Lewko, L.; Gornowicz, E. Effect of housing system on egg quality in laying hens. Ann. Anim. Sci. 2009, 11, 607-616. [CrossRef] 
138. Bejaei, M.; Wiseman, K.; Cheng, K.M. Developing logistic regression models using purchase attributes and demographics to predict the probability of purchases of regular and specialty eggs. Br. Poult. Sci. 2015, 56, 425-435. [CrossRef]

139. Chang, J.B.; Lusk, J.L.; Norwood, F.B. The price of happy hens: A hedonic analysis of retail egg prices. J. Agric. Resour. Econ. 2010, 35, 406-423. [CrossRef]

140. Lusk, J.L. Consumer preferences for cage-free eggs and impacts of retailer pledges. Agribusiness 2018, 35, 129-148. [CrossRef]

141. Napolitano, F.; Serrapica, M.; Braghieri, A. Contrasting attitudes towards animal welfare issues within the food chain. Animals 2013, 3, 551-557. [CrossRef] [PubMed]

142. Heng, Y.; Peterson, H.H.; Li, X. Consumer attitudes toward farm-animal welfare: The case of laying hens. J. Agric. Resour. Econ. 2013, 38, 418-434. [CrossRef]

143. Yeh, C.-H.; Menozzi, D.; Török, Á. Eliciting Egg Consumer Preferences for Organic Labels and Omega 3 Claims in Italy and Hungary. Foods 2020, 9, 1212. [CrossRef]

144. Gerini, F.; Alfnes, F.; Schjøll, A. Organic- and Animal Welfare-labelled Eggs: Competing for the Same Consumers? J. Agric. Resour. Econ. 2016, 67, 471-490. [CrossRef]

145. Parrott, P.; Walley, K.; Custance, P. Consumer defined dimensions of egg quality. In Proceedings of the XXI European Symposium on the Quality of Poultry Meat and XV European Symposium on the Quality of Eggs and Egg Products, WPSA, Bergamo, Italy, 15-19 September 2013. Available online: http://www.wpsa.com/index.php/publications/wpsa-proceedings/consumer-defined-dimensionsof-poultry-meat-quality/viewdocument/1145 (accessed on 15 July 2020).

146. Ochs, D.; Wolf, C.A.; Widmar, N.O.; Bir, C.; Lai, J. Hen housing system information effects on US egg demand. Food Policy 2019, 87, 101743:1-101743:9. [CrossRef]

(C) 2020 by the authors. Licensee MDPI, Basel, Switzerland. This article is an open access article distributed under the terms and conditions of the Creative Commons Attribution (CC BY) license (http://creativecommons.org/licenses/by/4.0/). 